\title{
Article \\ Facies Heterogeneity and Lobe Facies Multiscale Analysis of Deep-Marine Sand-Shale Complexity in the West Crocker Formation of Sabah Basin, NW Borneo
}

\author{
Muhammad Jamil ${ }^{1,2, *}$, Numair Ahmed Siddiqui ${ }^{1}$, Abdul Hadi Bin Abd Rahman ${ }^{1}$, Noor Azahar Ibrahim ${ }^{1}$, \\ Mohd Suhaili Bin Ismail ${ }^{1}$, Nisar Ahmed ${ }^{1}{ }^{1}$, Muhammad Usman ${ }^{1,3}{ }^{(\mathbb{D}}$, Zain Gul ${ }^{1}$ and Qazi Sohail Imran ${ }^{1}$ \\ 1 Department of Geosciences, Universiti Teknologi PETRONAS, Seri Iskandar 32610, Malaysia; \\ numair.siddiqui@utp.edu.my (N.A.S.); ar.abdul.hadi@gmail.com (A.H.B.A.R.); \\ azahar.ibrahim@utp.edu.my (N.A.I.); suhaili.ismail@utp.edu.my (M.S.B.I.); nisarpu12@gmail.com (N.A.); \\ usman.pu@outlook.com (M.U.); zain_17008726@utp.edu.my (Z.G.); qazi_17007588@utp.edu.my (Q.S.I.) \\ 2 Department of Earth Sciences, COMSATS University Islamabad, Abbottabad 22060, Pakistan \\ 3 Department of Earth and Environmental Sciences, University of Milan-Bicocca, Piazza Della Scienza 4, \\ 20126 Milan, Italy \\ * Correspondence: jamil287@gmail.com
}

\section{check for}

updates

Citation: Jamil, M.; Siddiqui, N.A.; Rahman, A.H.B.A.; Ibrahim, N.A.; Ismail, M.S.B.; Ahmed, N.; Usman, M.; Gul, Z.; Imran, Q.S. Facies Heterogeneity and Lobe Facies Multiscale Analysis of Deep-Marine Sand-Shale Complexity in the West Crocker Formation of Sabah Basin, NW Borneo. Appl. Sci. 2021, 11, 5513. https://doi.org/10.3390/app11125513

Academic Editor: Jianbo Gao

Received: 20 March 2021

Accepted: 14 April 2021

Published: 15 June 2021

Publisher's Note: MDPI stays neutral with regard to jurisdictional claims in published maps and institutional affiliations.

Copyright: (c) 2021 by the authors. Licensee MDPI, Basel, Switzerland. This article is an open access article distributed under the terms and conditions of the Creative Commons Attribution (CC BY) license (https:// creativecommons.org/licenses/by/ $4.0 /)$.
Featured Application: A generalized conceptual model for the characterization of a deep-marine siliciclastic complex deposition with respect to the integrated submarine fan and lobe architecture, which are essential for understanding the subseismic lithological heterogeneities in potential petroleum reservoirs of a deep marine environment.

Abstract: Deepwater lobes constitute a significant volume of submarine fans and are primarily believed to exhibit a simple sheet geometry. However, recent studies interpret the geometries of these deep-marine lobes as distinct with respect to the complexity of the facies and their distribution. Hence, a conceptual model of deep-marine sediments is essential to discuss the deep-marine sediments associated with the fan and lobe architecture. The present study highlights the facies heterogeneity and distribution of various lobe elements at a multiscale level by considering a case study of the West Crocker Formation of Sabah in northwest Borneo. The formation was logged on a bed-tobed scale from recently well-exposed sections, with a total vertical thickness of more than $300 \mathrm{~m}$. The lithological characteristics, bed geometry, sedimentary textures and structures of individual beds were used to categorize the rock units into nine sedimentary lithofacies: five sandstone lithofacies (S1-S5), one hybrid bed facies (H), two siltstone facies (Si1 and Si2) and one shale or mudstone facies (M). These facies were grouped into four facies associations (FA1-FA4), which were interpreted as lobe axis (FA1), lobe off-axis (FA2), lobe fringe (FA3) and distal fringe to interlobe (FA4) facies associations. This study is applicable for the distribution of lobes and their subseismic, multiscale complexities to characterize the potential of hydrocarbon intervals in deep-marine sand-shale system around the globe.

Keywords: deep-marine lobe-fan multiscale analysis; sedimentary facies and facies association; subseismic lithological complexities; northwest Borneo; sand-shale depositional system; West Crocker Fan

\section{Introduction}

Deep-marine siliciclastic deposition is primarily influenced by several factors, including the rate, type and source of sediments, sea level changes and tectonic settings [1-3]. These deposits are mainly present at the basin floor, constituting various submarine fans, which are considered one of the major hydrocarbon producing systems around the globe $[4,5]$. However, these fan deposits are highly complex due to variations in 
geometry, internal architecture and vertical and lateral distribution [6-8]. A range of processes related to sediment transportation and accumulation control the overall depositional characteristics of deep-marine sediments. Gravity-driven flows are one of the major sediment transport processes in a submarine depositional environment $[9,10]$. These flows principally encompass two endmembers: turbidity currents (frictional flow) and debris flow (cohesive flow) $[9,11,12]$. Such sedimentary processes and gravity flows result in the development of submarine fan and lobe systems. The classification of deep-marine fan and lobe deposits, with respect to sedimentary processes, requires the spatial distribution, thickness of individual units, sedimentary structures and variation in grain size [13,14].

Deep-marine lobes are considered a vital component of submarine fans [15-17], and they are radial features with thin apexes but distribute laterally like a fan toward the distal end $[18,19]$. However, the lobe deposition is more complex in terms of internal heterogeneity and the distribution of facies [20-22]. Various subenvironments (the lobe axis, off-axis, lobe fringe and distal lobe fringe) have been assigned to these lobe deposits with respect to their thicknesses and facies associations $[19,23]$. The excessive input of siliciclastic sediments from a shallow marine environment result in the significant internal heterogeneity and complex distribution of sediments in deep-marine lobes [20-22,24]. Later, because of substantial uplift and denudation, these gigantic sand deposits are exposed on the surface [25]. The study area selected for this project is present in the Malaysian part of Borneo, named Sabah, which contains extensive exposures of deep-marine fan deposits stratigraphically termed as the West Crocker Formation. In the case of our study area, with recent infrastructure development (Pan Borneo Highway construction in East Malaysia), numerous new outcrop sections were exposed as fresh roadcuts, which paved the way for the detailed analysis of facies heterogeneity and the distribution of various lobe elements in the West Crocker submarine fan.

The recent literature suggests that the sedimentary facies of deep-marine deposition are significantly diverse and complex when compared with the previous classic Bouma model [26]. Late Paleogene deep-marine sediments of the West Crocker Formation along the Pan Borneo Highway in West Sabah are mainly comprised of thin to thick and massive bedded sandstones, with some siltstone and shale units [27]. Although the previous studies describe Late Paleogene sediments in terms of several components of a submarine fan based on individual outcrops [27-30], this study highlights the multiscale heterogeneity to interpret the distribution of deep-marine lobe complex systems in the West Sabah Basin.

The study area included five studied locations of the Crocker fan, representing the sand-shale complex in West Sabah and having a total vertical thickness of more than $300 \mathrm{~m}$, principally on the roadsides from Kota Kinabalu to Telipok/Tuaran (Figure 1). The key objectives of the study included (1) analyzing the facies and facies distribution of several outcrop sections of the West Crocker Formation; (2) interpreting the differences in stacking patterns and architectural elements of the studied sections; and (3) evaluating the characteristics of various components of the submarine lobe complex. These sedimentological details were supportive to determine the depositional characteristics and distribution of lobe elements in the deep marine environment. This research work is intended to address the following research questions: What are the main facies heterogeneities and facies associations in the Oligocene West Crocker Formation? How we can relate these facies and facies associations into the multiscale lobe elements of the lobe axis, off-axis, lobe fringe and distal lobe? How could these lobe elements be effective for interpreting the individual lobe and lobe complexes for each outcrop section? The purpose of this study is to analyze the lobe architecture and the development of thickening and coarsening upward patterns, which are interpreted as a part of the individual lobe or lobe elements. 


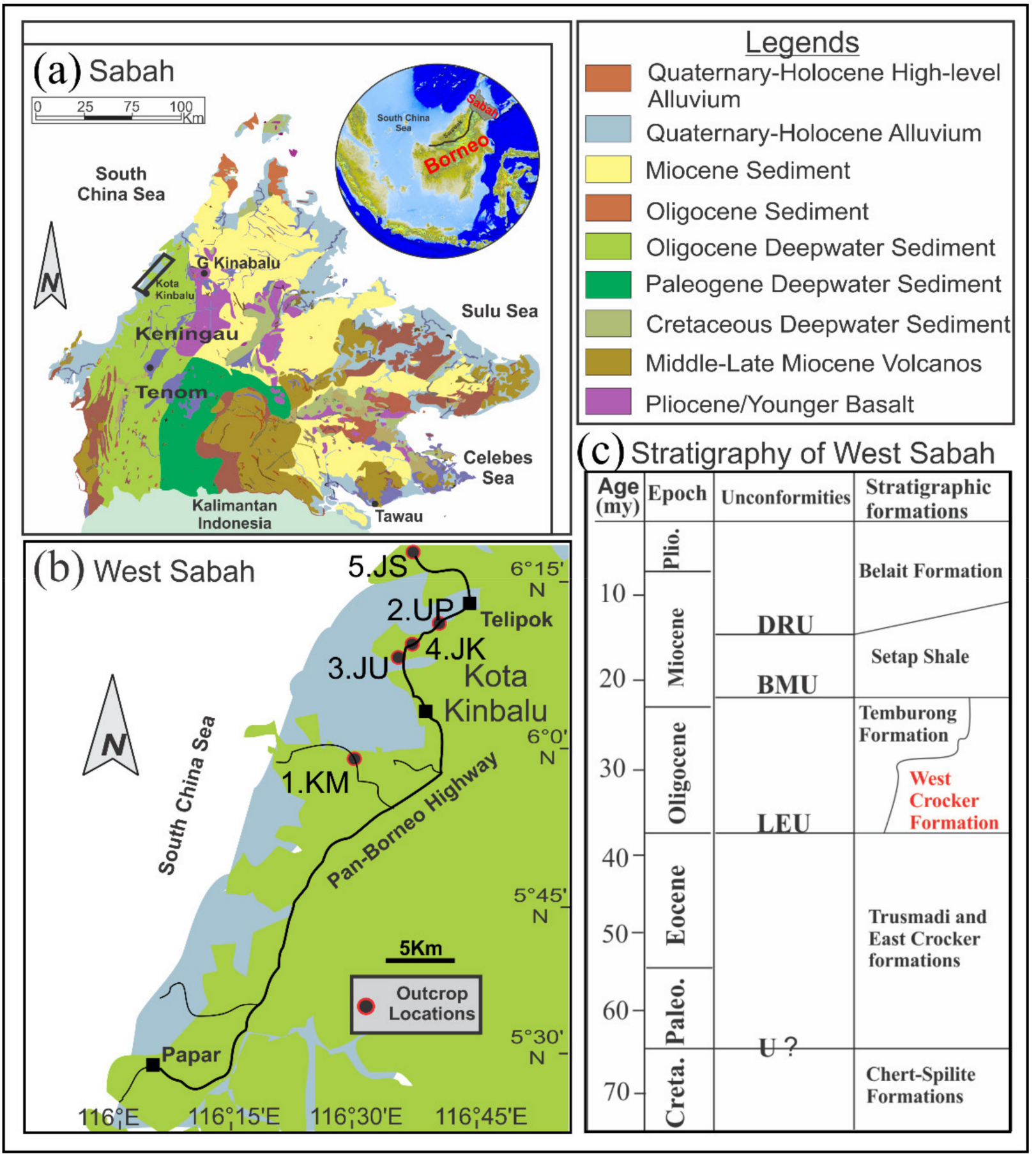

Figure 1. Location of the study area. (a) Regional map of Borneo bounded by the South China Sea in the west and the Celebes Sea and Sulu Sea to the east, with Sabah being in the northwest part of Borneo [31,32]. The study area is marked with a black rectangle in Sabah. (b) Map of the outcrop locations (1. The Kampung Madpai section (KM), 2. Prima University section (UP), 3. Jalan UMS section (JU), 4. Jalan UMS behind KFC section (JK), and 5. The Jalan Sulaman section (JS)), mainly located along roadsides in the area from Kota Kinabalu to Telipok. (c) Generalized stratigraphy of West Sabah with the Oligocene age of the West Crocker Formation, where late Eocene unconformity (LEU) is present at the base while the top of the West Crocker Formation is marked by base Miocene unconformity (BMU) [28].

\section{Geological Background}

The northwest Sabah Basin is considered as one of the major Tertiary depositional systems of northwest Borneo, having two distinct phases of sedimentation. The older 
deposition is termed as the Rajang Group, mainly comprised of the Paleocene to Eocene Trusmadi and East Crocker formations. These deposits were later uplifted and eroded to form late Eocene unconformity (LEU). After this LEU unconformity, the second phase of deposition started from the late Eocene to early Miocene epochs (West Crocker and Temburong formations) $[28,29,33]$. The present study focuses only on the second phase of deep-marine Tertiary deposition (late Paleogene) in the northwest Sabah Basin.

\subsection{Deep Marine Environment, Processes and Lobe Complex}

Deep-marine siliciclastic deposits are vital for the petroleum industry, with respect to hydrocarbon exploration, with a gradual increase in exploration for huge petroleum discoveries in a large volume of deep-water sediments [34]. The development of these deep-marine deposits is the result of various sedimentary processes, which resulted in numerous architectural elements and sedimentary facies [35-38]. In the deep marine environment, the components of a submarine fan are dependent on the distribution and variation of density flows and flow processes. Low-density turbidity flows are common in all subenvironments of deep-marine systems but are mostly abundant in the distal part of a submarine fan [39]. High-density flow processes are commonly associated with the feeder channels and distributary channels of a lobe in a submarine fan system. The variation in the thickness of sand units is also responsible for a variety of facies associations and depositional environments, such as the massive or thick-bedded sandstone with rare shale unit being most likely associated with the proximal lobe deposition. The lateral variation in the sedimentary succession of the individual lobe can be depicted from a decrease in the thickness of sand units with respect to neighboring shales, which represents the distal part of a submarine fan. The thickening up stacking patterns of lobes could be the result of the progradation of individual lobes [15,39-41].

In order to understand the paleoenvironments and facies analysis, the classical Bouma sequence has limited applications for deep-marine lobe systems [26,42]. Certain terminologies emerged in the past decade to refine the classification of deep-marine sediments. For example, the term "hybrid bed" is a product of the deceleration or transition of the turbidity current to mixed turbidite events $[11,43,44]$. Flow transformation is characterized by the erosion of underlying rock units within the feeder channels and the axial or proximal part of the lobe. The transition of flow from turbulent to laminar results in the development of heterogeneity in the form of hybrid beds, owing to the deceleration and expansion of flow $[11,44,45]$.

Recent investigations explained that the deep-marine sand sheet or fan deposits included a feeder channel with several individual lobes $[19,46]$. The relative age of each lobe may vary as the older lobe may be overlapped by the younger one (Figure 2), and this overlapping of lobes may continue in a lobe complex [19,47]. The lobe complex can be classified based on the relative position of the feeder channel. Those present close to the feeder channel are termed as proximal lobes (Figure 2), the middle part of lobe complex is called the medial lobes, while those farther away from the medial lobes are labeled as distal lobes [24]. 


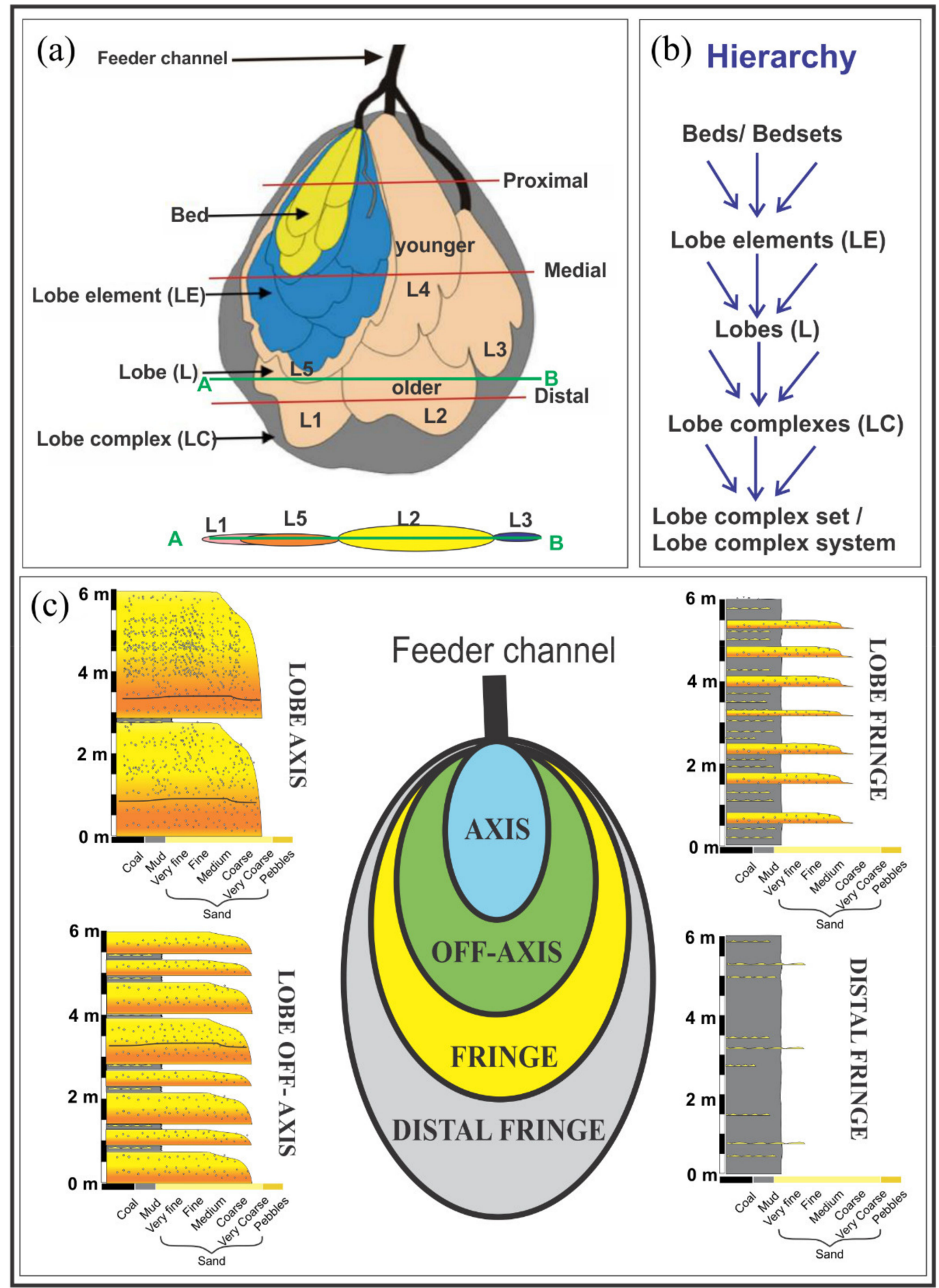

Figure 2. Lobe terminology used for the discussion of facies heterogeneity and multiscale analysis of the lobe complex system. (a) Classification of the lobe complex into proximal, medial, and distal parts of the individual lobes [24,46]. (b) Hierarchy of the lobe system, where the smallest unit is the bed or bed set while the largest unit is known as the lobe complex set [47] or lobe complex system. (c) Characterization of the lobe, with a feeder channel into the lobe axis, off-axis, fringe and distal fringe, each with representative logs $[14,19,48]$.

Lobes are divided into four subenvironments-the lobe axis, lobe off-axis, lobe fringe (both frontal and lateral) and distal lobe fringe - on the basis of the amount of sand, amalgamated surfaces and sedimentary facies $[17,45,49,50]$. The lobe axis is predominantly composed of structureless, thick-to-massive bedded sandstone with amalgamation, indi- 
cating greater depositional rates with high energy turbidity currents $[17,48]$. The growth of the lobe off-axis mainly results from the deposition of medium-to-thick bedded sandstone, representing relatively low deposition rates and low energy turbidity deposits [17]. The deposition of the lobe fringe is mainly characterized by thin-bedded sandstone (fine grained and rippled) with the hybrid event beds, which are created due to the transformation of flow $[17,45,48]$. However, the distal lobe fringe or interlobe only contain thin-bedded siltstone and thick-to-massive shale units [14,48].

\subsection{Paleogene and Neogene Geology of West Sabah}

Borneo has a complex geological history of sedimentation and deformation, especially in the Tertiary period, when a large volume of sediments was transported from southern Borneo, namely the Schwaner Mountains and the Tin Belt, resulting in the huge thickness of deep-marine deposits [29,30,51]. The development of Borneo is associated with tectonic subduction, along with the obduction of ophiolite rocks and the collision of tectonic fragments with the continental part of the Sunda Plate, resulting in the closure of paleobasins [31,52-54]. The Borneo Accretionary Orogen is present in the center of South East Asia, which is bounded by the subduction of the Pacific and Indian plates with a passive continental margin of the South China Sea. The Borneo Accretionary Orogen is currently active, as the subduction of the Dangerous Grounds under the Borneo Block is still continuous [55].

Northern Borneo comprises the Sabah Basin at the geological complex junction between Sunda, Celeb, Sulu and the South China Sea, where Tertiary sediments are exposed due to the Sabah orogenic belt, which resulted in the closure of the South China Sea [51,56-60]. The post-orogenic foreland Sabah Basin is mainly comprised of marine sediments, where the depositional processes were disrupted by several tectonic events in the form of unconformities. These unconformable surfaces are well-preserved in the Paleogene and Neogene stratigraphic record of West Sabah [61]. The Top Crocker Unconformity (TCU) or Base Miocene Unconformity (BMU) is the major unconformity separating the Late Paleogene West Crocker Formation from the Neogene Setap Shale [62]. The northwest Sabah Basin is mainly comprised of the Crocker fold and thrust belt (CFTB), which is also termed as the Crocker Range $[29,63,64]$. The Crocker fold and thrust belt was developed due to the collision of continental plates and largely consists of siliciclastic sediments of the deep marine environment [52].

\subsection{West Crocker Formation}

The West Crocker Formation crops out in the form of several vertical to subvertical rock sections around Kota Kinabalu and generally in the West Sabah [61,65]. The late Paleogene Crocker sediments were deposited by erosion of the early Paleogene rocks. The thickness of the late Paleogene sediments varies from at least $1000 \mathrm{~m}$ to more than $2000 \mathrm{~m}$, and the lithologies include sandstone, shales and siltstones [30,33,66]. Late Paleogene sediments mainly consist of sand-dominated debris flow deposits and heterolith siltstone mudstones, having all components of the inner, middle and outer fan environments [27], while at a few studied sections, the formation is interpreted to be only a middle-to-outer fan system [67]. These sediments are mainly sand-rich facies deposited by high density turbidity currents; however, they also contain low-density turbidites and mass-transport deposits like slumps and contorted layers [68,69].

High-density turbidity flows result in texturally immature, poorly sorted and angular fragments in siliciclastic rocks [30,70-72]. Sedimentary structures like flute marks, cross bedding, convolution, parallel lamination, amalgamation and dish structures have been reported [27]. Water escape dish structures and convolution are the result of rapid deposition [73] and are termed as soft sediment deformation structures (SSDSs). These deformation structures are inferred to be seismites, which are representative of active tectonic settings [74]. The early Paleogene Rajang Group was eroded and resedimented to form the late Paleogene rocks of the West Crocker Formation [72]. 


\section{Materials and Methods}

\subsection{Geological Fieldwork}

The dataset included sedimentological logs and lithological details from outcrops. Standard field geological operations were followed to delineate the detailed sedimentary evaluation of the West Crocker Formation in West Sabah. The best-exposed sections were selected for the detailed sedimentological description of rock units with the help of available geological maps, google satellite imagery as well as several reconnaissance field visits. Measurements of the vertical thicknesses of the beds, identification of numerous sedimentary structures and grain size variations and descriptions of the geometries of rock units were noted for understanding complexities. These details were quite helpful to discuss the facies heterogeneity and lobe systems of deep-marine multiscale sedimentary successions. The methodology was used for classifying the deep-marine sediments into sedimentary lithofacies based on variations in bed thickness, grain size and types of sedimentary features. These sedimentary facies were grouped into facies associations, which were interpreted to be part of the submarine lobe environment.

\subsection{Field Sedimentary Logging and Facies Analysis}

The dataset comprised of detailed sedimentological characterization of the outcrops, including (1) the Kampung Madpai (KM) section, (2) the Jalan Universiti Prima (UP) section, (3) the Jalan UMS (JU) roadside, (4) the Jalan UMS behind KFC (JK) section and (5) the Jalan Sulaman (JS) section around Kota Kinabalu (Figure 1). These logs contained the particulars of individual rock units, including the bed thickness, lithological character, sedimentary structures and types of bed contacts. These details were investigated to analyze, evaluate and interpret the complexity of the deep-marine exposed sections. The field sedimentary details were applied to interpret the facies analysis and facies association, which were correlated with the submarine lobe architecture (e.g., lobe element, lobe complex and composite lobe system).

\subsection{Sandstone Thickness Analysis and Trends}

The pattern of thickness of rock units varied considerably, like how thin-bedded sand units were related to distinct elements of lobe fringes while thick-bedded sands were linked to the proximal part of the lobe. These thin or thick beds were indicative of the flow conditions, such as interbedded, thin-bedded sandstones and siltstone representing low-density turbidity flows while thick-bedded or massive sandstones indicating highdensity flow conditions. These thick-bedded sand units were quite established by feeder channels in the axial or off-axial parts of the lobes $[75,76]$. However, lobe progradation could generally be linked with thickening up cycles, or it could be the onset of a new individual lobe. The medial and distal frontal fringe lobe were associated with hybrid units and were the result of a downward dip of high-density turbidites or low-density flows, representing the lower part of the prograding lobe succession [77].

Deepwater lobes are explained as simple radial deposits which are fine and thin in morphology at the initiation point or feeder channel, but they are more complex with respect to their geometry and facies characterization. These lobes are further classified by the relative thickness of the sand and shale beds. The lobe complex is the larger entity of lobe deposition that is primarily comprised of a feeder channel and individual lobes, having a variety of morphologies and geometric distributions $[19,23,46]$.

\section{Results and Interpretations}

\subsection{Stratigraphic Distribution of Outcrop Sections}

Geological field logs explained the stratigraphic distribution of each outcrop in the study area. Recently exposed road cuts and fresh exposures were selected to study the West Crocker Formation. In general, the stratigraphy was sand-dominated sections with multimeter sand beds present throughout the outcrops. It is pertinent to mention here the Kampung Madpai outcrop (KM) contained mainly massive sand units with thin shale 
laminae, and massive shale beds were completely absent, representing the inner part of the submarine fan. The basal part of the Prima University section (UP) contained both shale and sand beds, and the middle part of the section contained massive sandstone intervals while the upper part of the outcrop contained thick-to-massive sandstone (Figure 3) with little influx of shale, representing the middle part of the submarine fan.

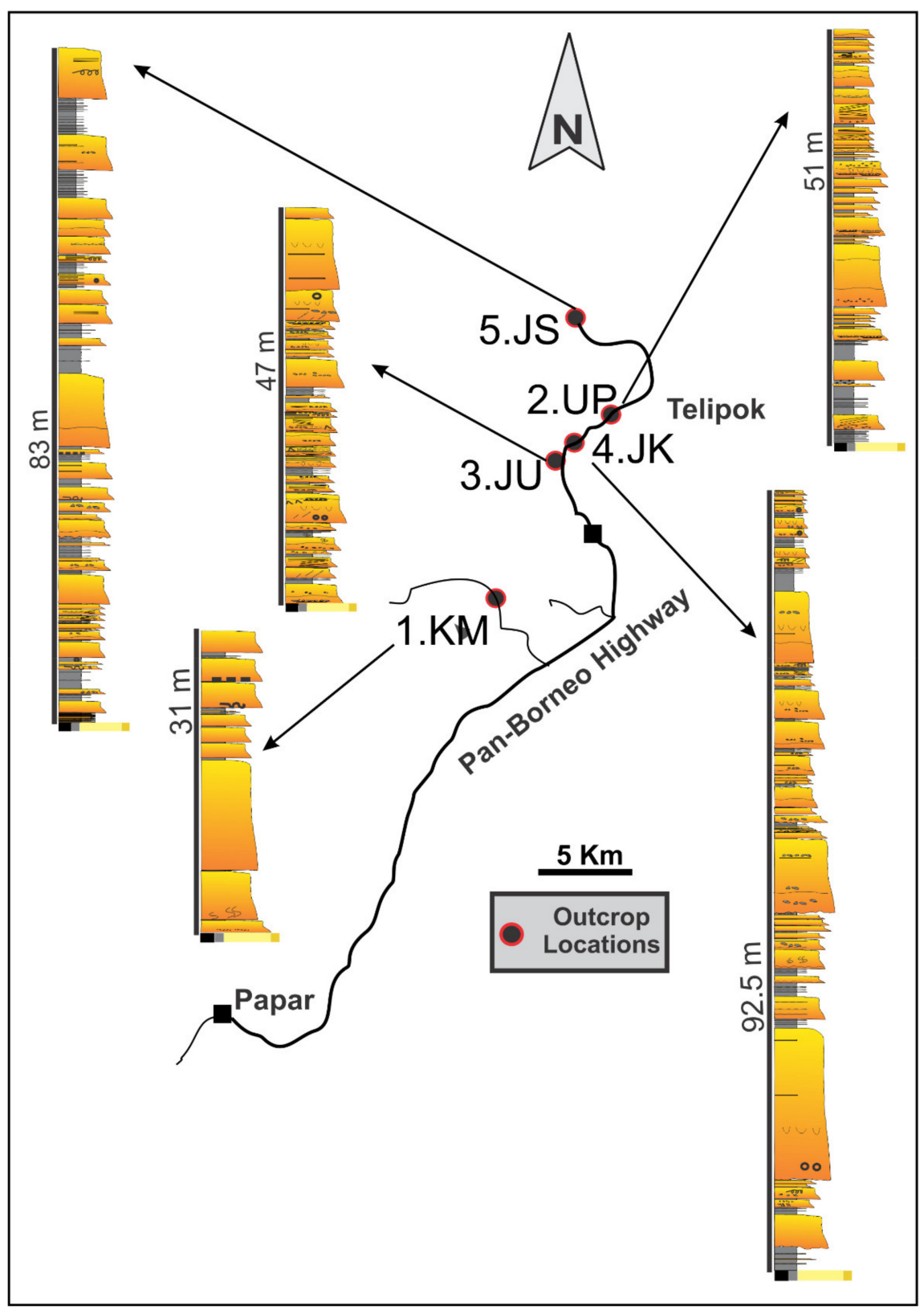

Figure 3. Stratigraphic distribution of the selected exposed outcrops that represent the multiscale sand-shale complex system. These lithological heterogeneities are interpreted as various components of the submarine fan-lobe architecture.

The lower part of the Jalan UMS road section (JU) comprised thick-bedded to massive sandstone beds, while the upper part of the section predominantly consisted of only massive multimeter sandstone beds, representing a high influx of sand, which is characteristic of a proximal fan environment. These massive beds were also common in the lower part of the Jalan UMS behind KFC section (JK), and the upper part was characterized by massive sandstone and shale intervals. The Jalan Sulaman section (JS) is a classic example 
of massive sandstone beds with alternate massive shale representing the cyclicity in the lobe-fan deposition.

\subsection{Facies Analysis and Depositional Environment}

A facies is defined as a rock unit comprising one or more beds which has specific characteristics, such as composition, bed thickness or texture. These facies are distinctive rock units which have been developed by a geological process and are indicative of certain conditions of sedimentation [42]. The clastic sedimentary rock units present in the study area were classified based on sedimentary structures and lithology, in which the sandstones are denoted with sandstone lithofacies $(\mathrm{S})$, hybrid event beds $(\mathrm{H})$, siltstone lithofacies $(\mathrm{Si})$ and mudstone or shale lithofacies (M). These lithofacies were numbered according to each type of sedimentary facies.

\subsubsection{S1 Facies: Graded Coarse-to-Fine-Grained Sandstone}

The physical characteristics of this facies included thick-to-massive bedded sand units, mainly poorly sorted, some beds have normal grading and fine-to-coarse-grained sandstone units. The thicknesses of individual sand units ranged from $30 \mathrm{~cm}$ to more than $100 \mathrm{~cm}$. Many sand units in this facies had thicknesses more than $2 \mathrm{~m}$, which were often amalgamated. Based on amalgamation structures, the facies were interpreted as a result of multiple depositional events and a high-energy environment [11]. Moreover, a high vertical thickness and multimeter individual sand units were the result of a high sediment influx in a basin, where the lower part was characterized by high-density flow deposition, Ta division [78] or F5 and F8 facies [79].

\subsubsection{S2 Facies: Ungraded Coarse Sandstone (Structureless)}

The sandstone units were moderately sorted, having coarse to very coarse grain sizes (Figure 3). The thicknesses of the sand beds ranged from thick-bedded to massive (more than $30 \mathrm{~cm}$ up to $5 \mathrm{~m}$ ). Most of the units had no grading and limited variation in grain size, which were termed as structureless and moderately sorted. Sand beds are often amalgamated showing tabular geometry and mainly lack any sedimentary structures. The facies was deposited by high-density turbidity currents, containing a traction carpet and classified as the S2 type [18,80], the lower part of Ta division by [78], and the flow is termed as dense sandy and gravely flow [79].

\subsubsection{S3 Facies: Parallel Laminated Fine-to-Medium-Grained Sandstone}

The thicknesses of sand units fluctuated from thin- to medium-bedded, while the grain size ranged from fine- to medium-grained sand. These beds exhibited parallel laminations and, in a few cases, laminated muddy sandstone were present. The parallel laminations $(\mathrm{Tb})$ were often present above the massive structureless $(\mathrm{Ta})$ units, indicating high energy conditions. The parallel stratification (Figure 4) indicated the near-bed suspension generated by progressive turbulent flow, where the rate of deceleration was relatively sluggish [81]. The facies was classified as the $\mathrm{S} 3$ type of sediment [80], with the $\mathrm{Tb}$ after Bouma [78] and F7 and F9 facies [79] representing high density turbidity currents [82,83].

\subsubsection{S4 Facies: Ripple-Laminated Sandstone}

The facies included fine- to very fine-grained sandstone showing ripple cross-lamination. These units were thin- to thick-bedded sands. The height of the ripple lamination may have varied from 4 to $10 \mathrm{~cm}$ (Figure 4C), and length ranged from $10 \mathrm{~cm}$ to $32 \mathrm{~cm}$. The deposited rock unit indicated the lower flow regime and was marked as Tc [78] and F9 facies by [79]. These cross laminations were interpreted to be the result of a change in flow regime from higher energy to transitional or a low energy environment and loss of flow confinement. These facies are more frequently found in lobe off-axis settings [84]. 


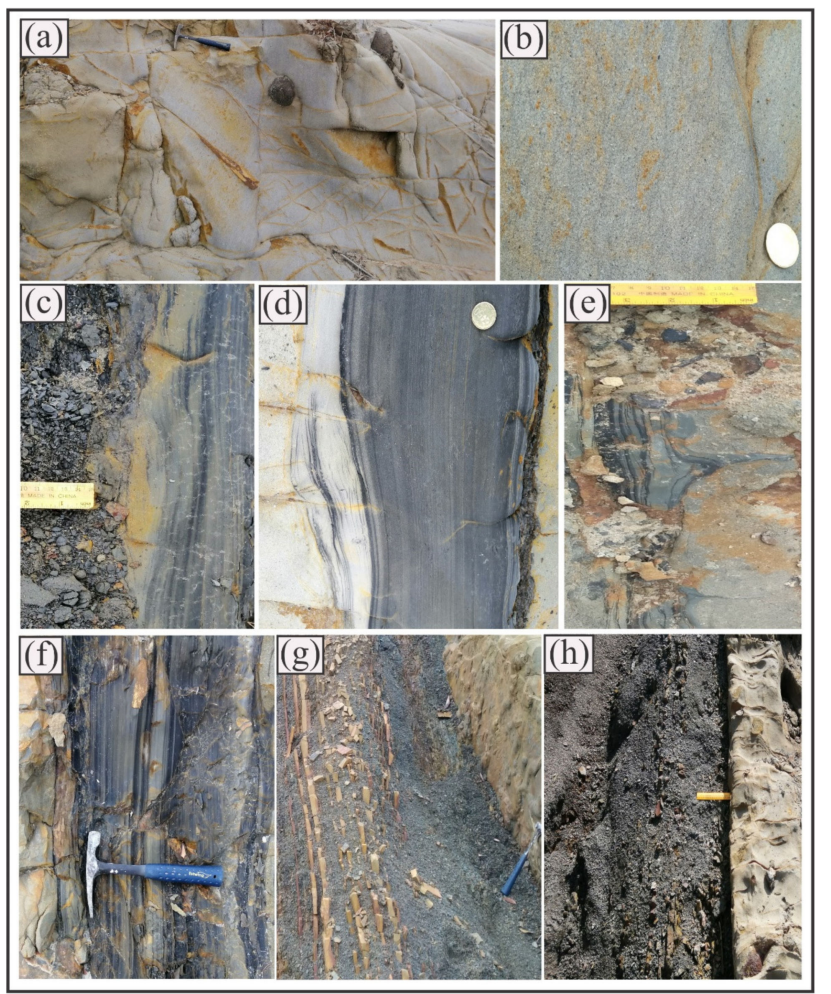

Figure 4. Sedimentary facies. (a) Amalgamated massive sand with floating mud clasts in the Jalan UMS road section, interpreted to be S1 lithofacies. (b) Massive, coarse-grained sandstone at the Jalan UMS road section, which belongs to the S2 facies. (c) Parallel lamination S3 facies and crosslamination S4 facies in the Jalan UMS road section. (d) Parallel laminated S4 facies at the Jalan UMS road section. (e) Flame structure S5 facies. (f) Laminated siltstone facies Si1 at the Jalan UMS KFC section. (g) Laminated muddy siltstone Si2 facies at the Jalan UMS KFC section. (h) Massive dark shale or mudstone $\mathrm{M}$ facies at the University of Prima Condo road section.

\subsubsection{S5 Facies: Medium- to Fine-Grained Soft Sediment Deformation Units}

Convoluted lamination due to the deformation of unlithified sand units [74] is a typical characteristic of this sedimentary succession (Figure 5). The deformation of sandstone units varied from gentle to moderately strong, which indicates variation in the degree of deformation. Flame structures are also present in a few units, representing the facies at the hydraulic jump interprets to be a part of the proximal lobe [39]. Dewatering of unlithified clastic units due to the upward movement of fluids and some particles which had deformed the overlying strata can also be present [85]. The phenomenon of the generation of a deformational structure (Figure 5) is related with the fluidization process that develops the instabilities in the gravity flows, or it may also be related to seismic activity [74].

\subsubsection{H Facies: Hybrid Event Beds}

Hybrid beds are characterized by intermediate flow behavior comprised of two arrangements of lower mud-deficient sand overlain by a mud-rich sand interval, and various terms were assigned like slurry flows [18], transitional flow deposit [9], linked debrite [86], hybrid event [87] and matrix-rich sand [88]. The hybrid beds are often termed as bi- or tripartite beds, depending on the characteristics of the underlying and overlying units, and vary significantly from the downslope of the channelized to the unconfined area. Lateral lobe fringes are predominantly low-density turbidites and have hybrid events [23,45]. 


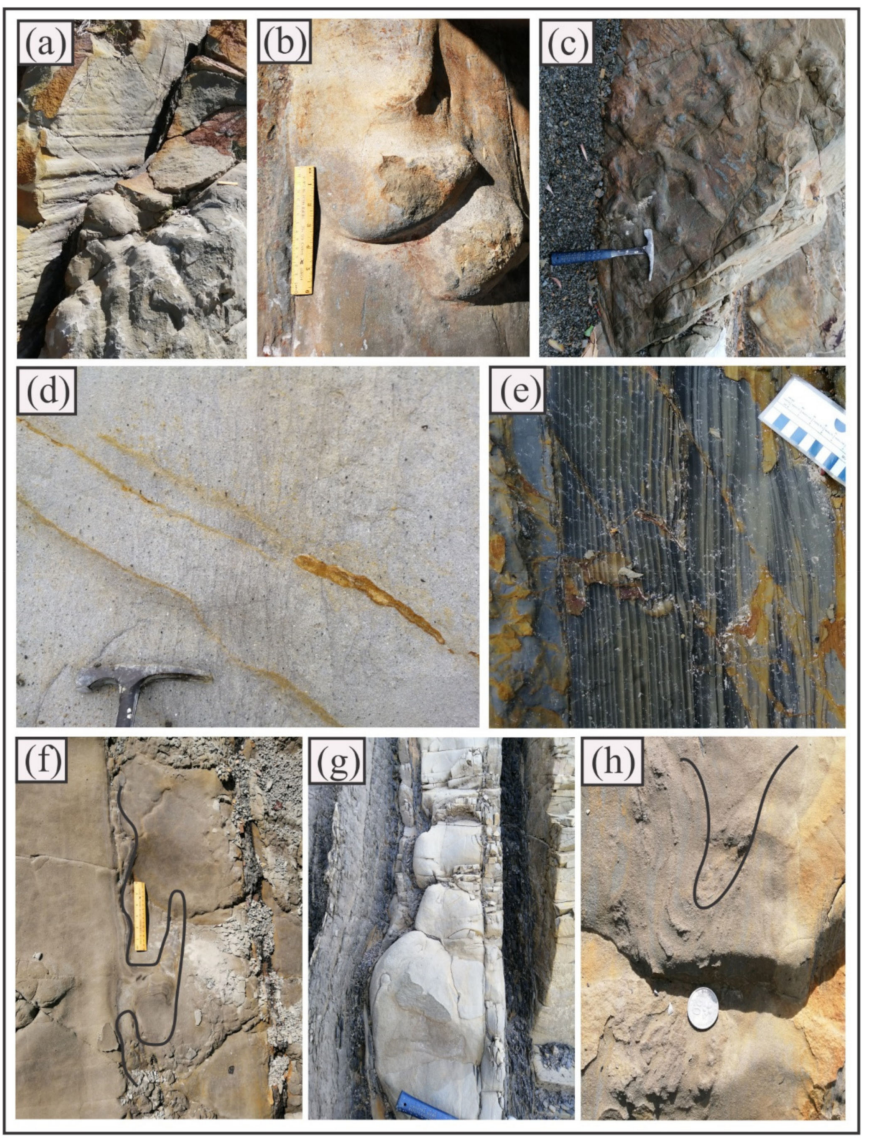

Figure 5. Sedimentary structures. (a) Tool marks in the Kampung Madpai section. (b) Load casts in the Kampung Madpai section. (c) Flute casts at the base of the sandstone in the Jalan UMS KFC outcrop. (d) Massive coarse-grained sandstone with dewatering in the Jalan UMS KFC section. (e) Ripple and parallel laminations in the Jalan UMS KFC section. (f) Flame structure in the Jalan Sulaman outcrop. (g) Load structure in the Jalan Sulaman section. (h) Convolute lamination in the Jalan Sulaman outcrop.

A great variety of lithofacies can be prevalent within the hybrid units and are also variable within the individual beds over a scale of centimeters to meters. These hybrid beds contain both the characteristics of turbidite and debrite within the same depositional event. The scales of thickness of hybrid beds vary considerably from tens of centimeters to more than a meter, which is associated with the influx of sediments deposited within the single event of hybrid flow. The hybrid beds in the study area (Universiti Prima road section) consisted of only three divisions (H1, H3 and H5) of hybrid event deposition [43]. The basal structureless graded sandstone (H1), overlain by a banded sand unit (H2), was composed of both sand and shale (irregular) bands. The third division was more chaotic (H3), having patches of sand with more mud, with the fourth subdivision having a laminated sand mud unit (H4) capped by a clayey shale unit (H5).

\subsubsection{Si1 Facies: Laminated Siltstone}

The facies represent the siltstone units, which are laminated siltstone and range in thickness from 6 to $17 \mathrm{~cm}$. The major lithology was siltstone in the form of thin to laminated units with interbeds of shale or mudstone. Fine sand units and silt laminations are common in this facies, alternating with mudstone or shale lamination. The traction fallout and low energy depositional environment, or the diluted turbidity currents in the hemipelagic settings [11], are the possible explanations of these heterolithic facies, which were deposited from a suspension during a lower flow regime. This facies is equivalent to the Bouma Td division, representing a low-density flow deposit (Table 1). 
Table 1. Summary of sedimentary facies, with their descriptions, outcrop locations and interpretations.

\begin{tabular}{|c|c|c|c|c|c|}
\hline No. & Facies & Description & Sedimentary Log & Location & Interpretation \\
\hline 1 & $\begin{array}{l}\text { S1 facies } \\
\text { (sandstone) }\end{array}$ & $\begin{array}{l}\text { Thick to massive } \\
\text { sandstone } \\
\text { Normal grading } \\
\text { Amalgamated }\end{array}$ & 0000 & $\begin{array}{l}\text { Basal and upper part of } \\
\text { the Jalan UMS } \\
\text { road section }\end{array}$ & $\begin{array}{l}\text { Rapid } \\
\text { accumulation } \\
\text { High-density } \\
\text { currents } \\
\text { Ta Bouma }\end{array}$ \\
\hline 2 & $\begin{array}{c}\text { S2 facies } \\
\text { (sandstone) }\end{array}$ & $\begin{array}{l}\text { Structureless sand- } \\
\text { stoneUngraded } \\
\text { Amalgamated } \\
\text { Coarse- to very } \\
\text { coarse-grained }\end{array}$ & & $\begin{array}{l}\text { Basal part of the } \\
\text { Kampung Madpai } \\
\text { section } \\
\text { Middle part of the Jalan } \\
\text { UMS road section }\end{array}$ & $\begin{array}{c}\text { Lower part of the } \\
\text { Ta Bouma facies } \\
\text { Sandy and gravely } \\
\text { flow [79] }\end{array}$ \\
\hline 3 & $\begin{array}{c}\text { S3 facies } \\
\text { (sandstone) }\end{array}$ & $\begin{array}{c}\text { Thin- to } \\
\text { medium-bedded } \\
\text { Parallel-laminated } \\
\text { Fine- to } \\
\text { medium-grained }\end{array}$ & & $\begin{array}{l}\text { Lower part of the Jalan } \\
\text { UMS road section } \\
\text { Middle part of the Prima } \\
\text { University section }\end{array}$ & $\begin{array}{l}\text { Tb Bouma facies } \\
\text { F7 and F9 } \\
\text { facies [79] }\end{array}$ \\
\hline 4 & $\begin{array}{l}\text { S4 facies } \\
\text { (sandstone) }\end{array}$ & $\begin{array}{l}\text { Ripple lamination } \\
\text { Fine- to very } \\
\text { fine-grained } \\
\text { Thin- to } \\
\text { thick-bedded }\end{array}$ & & $\begin{array}{l}\text { Basal part of the Jalan } \\
\text { UMS road section } \\
\text { Basal part of the Prima } \\
\text { University section }\end{array}$ & $\begin{array}{l}\text { Tc Bouma facies } \\
\text { F9 Mutti facies } \\
\text { Lower flow regime }\end{array}$ \\
\hline 5 & $\begin{array}{l}\text { S5 Facies } \\
\text { (sandstone) }\end{array}$ & $\begin{array}{l}\text { Soft sediment } \\
\text { deformation } \\
\text { Thickly to } \\
\text { massively bedded } \\
\text { Medium- to } \\
\text { coarse-grained }\end{array}$ & & $\begin{array}{l}\text { Lower part of the } \\
\text { Kampung Madpai } \\
\text { section } \\
\text { Middle part of the Jalan } \\
\text { UMS section }\end{array}$ & $\begin{array}{l}\text { Proximal part of } \\
\text { the lobe } \\
\text { Tc Bouma facies }\end{array}$ \\
\hline 6 & $\begin{array}{c}\mathrm{H} \text { facies } \\
\text { (hybrid event) }\end{array}$ & $\begin{array}{l}\text { Bipartite or } \\
\text { tripartite beds } \\
\text { Rich in mud and } \\
\text { broken clasts }\end{array}$ & $=$ & $\begin{array}{l}\text { Lower part of the Prima } \\
\text { University section }\end{array}$ & $\begin{array}{l}\text { Transitional flow } \\
\text { Intermediate } \\
\text { flow behavior }\end{array}$ \\
\hline 7 & $\begin{array}{l}\text { Si1 facies } \\
\text { (siltstone) }\end{array}$ & $\begin{array}{l}\text { Siltstone units } \\
\text { Very thin to thin } \\
\text { units } \\
\text { Rare interbeds of } \\
\text { shale or mudstone }\end{array}$ & 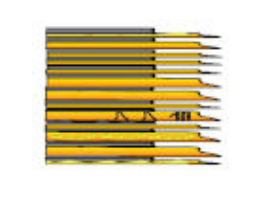 & $\begin{array}{l}\text { Lower and upper parts } \\
\text { of the Jalan UMS } \\
\text { KFC section }\end{array}$ & $\begin{array}{l}\text { Suspension fallout } \\
\text { Bouma Td facies } \\
\text { Low density }\end{array}$ \\
\hline 8 & $\begin{array}{l}\text { Si2 facies } \\
\text { (siltstone) }\end{array}$ & $\begin{array}{l}\text { Higher mud } \\
\text { content in siltstone } \\
\text { Laminations are } \\
\text { discontinuous }\end{array}$ & & $\begin{array}{l}\text { Upper part of the Jalan } \\
\text { UMS KFC section } \\
\text { Lower part of the Prima } \\
\text { University section }\end{array}$ & $\begin{array}{l}\text { Dilute sediment } \\
\text { gravity flow } \\
\text { Td-Te } \\
\text { Bouma facies }\end{array}$ \\
\hline 9 & $\begin{array}{c}\text { M facies } \\
\text { (mudstone or } \\
\text { shale) }\end{array}$ & $\begin{array}{l}\text { Mainly shale } \\
\text { Thickly to } \\
\text { massively bedded } \\
\text { Lacking internal } \\
\text { structures }\end{array}$ & & $\begin{array}{l}\text { Upper part of the Jalan } \\
\text { UMS KFC section } \\
\text { Basal part of the Prima } \\
\text { University section }\end{array}$ & $\begin{array}{l}\text { Te Bouma facies } \\
\text { Mud turbidites } \\
\text { Final deposition of } \\
\text { sediment } \\
\text { gravity flow }\end{array}$ \\
\hline
\end{tabular}

\subsubsection{Si2 Facies: Laminated Muddy Siltstone}

Laminated to medium-bedded siltstone beds with shale or mudstone layers were included in this sedimentary facies. The amount of mud or argillaceous material was relatively higher than the siltstone units. The siltstone lamination could be discontinuous due to more shale material, where these lithological characteristics are associated with lobe 
fringes or distal lobe settings [19]. Numerous individual lobes are usually separated by muddy siltstone intervals. Suspension fallout occurs due to a low energy of flow from a relatively dilute sediment gravity flow. It is also interpreted as change in swiftness of flow and a lower sediment influx. The shale input increases in this type of sedimentary facies, which indicates the energy conditions equivalent to Bouma Td-Te facies. Argillaceous sediments present in the turbidity currents were finally settling down in the lower flow regime.

\subsubsection{Mudstone (M) or Massive Shale Facies}

The massive shale or mudstone facies predominantly contained thick-bedded to massive shale units although, it may have held a little influx of silt laminae. However, the thickness of shale or mud was considerably larger than the silt laminae, which indicates the strong influx of shale or mud in the sedimentary basin. These mudstone facies represent the lateral lobe settings [19] that separate the individual lobe or lobe complex. A massive mudstone interval could also be evident from the most distal part of the lobe environment. The term "interlobe" is also used for massive shale intervals to differentiate between deposition of the multiple lobes in a submarine environment [22,24,41]. The mudstone or shale primarily lacked any internal structures. The facies was equivalent to Bouma Te facies or T6 or T7 Stow's classification $[89,90]$ and was termed as mud turbidites. These units represent the final deposition from the phase of sediment gravity flow [91].

\subsection{Facies Associations and Lobe Complexity}

In this section, the outcrop sections are discussed with respect to various thickening or thinning cycles based on the range of thickness of the individual sand units. These cycles or trends are quite useful to relate the outcrop sections with lobe elements and lobe progradation, aggradation or cessation. The dynamics of the lobe in a deep marine system were quite evident from the thickening or thinning trends. Additionally, the lithological units were categorized into lobe elements, which were grouped into lobes and further into lobe complexes. Several individual sedimentary facies were identified for any rock formations, which were later grouped and categorized into facies associations [42]. Several facies associations were identified based on the facies analysis of lithological beds, including sandstone, siltstones and shales or mudstones. These facies associations are essentially connected with various components of submarine lobe deposits [17] equivalent to the proximal lobe or axial lobe (FA1), lobe off-axis (FA2), lobe fringe (FA3) and distal lobe fringe or interlobe (FA4).

\subsubsection{Facies Association 1 (FA1): Lobe Axis}

Lobe axis facies association is characterized by massive sandstone units, generally having thicknesses of more than $100 \mathrm{~cm}$. The thickness of an individual sand unit may go up to more than $800 \mathrm{~cm}$. These units are often structureless as there is no grading and only a minor change in grain size within the sand beds. Multimeter massive sandstone with an amalgamation structure is the characteristic of this facies. S2 and S5 facies and occasionally $\mathrm{S} 1$ facies are included in this facies association. The association of this facies is interpreted as unconfined lobe settings with lobe axis and lobe off-axis alternate beds that are stacked together [92,93], having amalgamated bodies (Figure 6) representing the proximal part of the lobe system. The facies is associated with high-density turbidity currents, where the huge amount of sand influx with rare or no argillaceous content is indicative of a lobe axis depositional environment. 


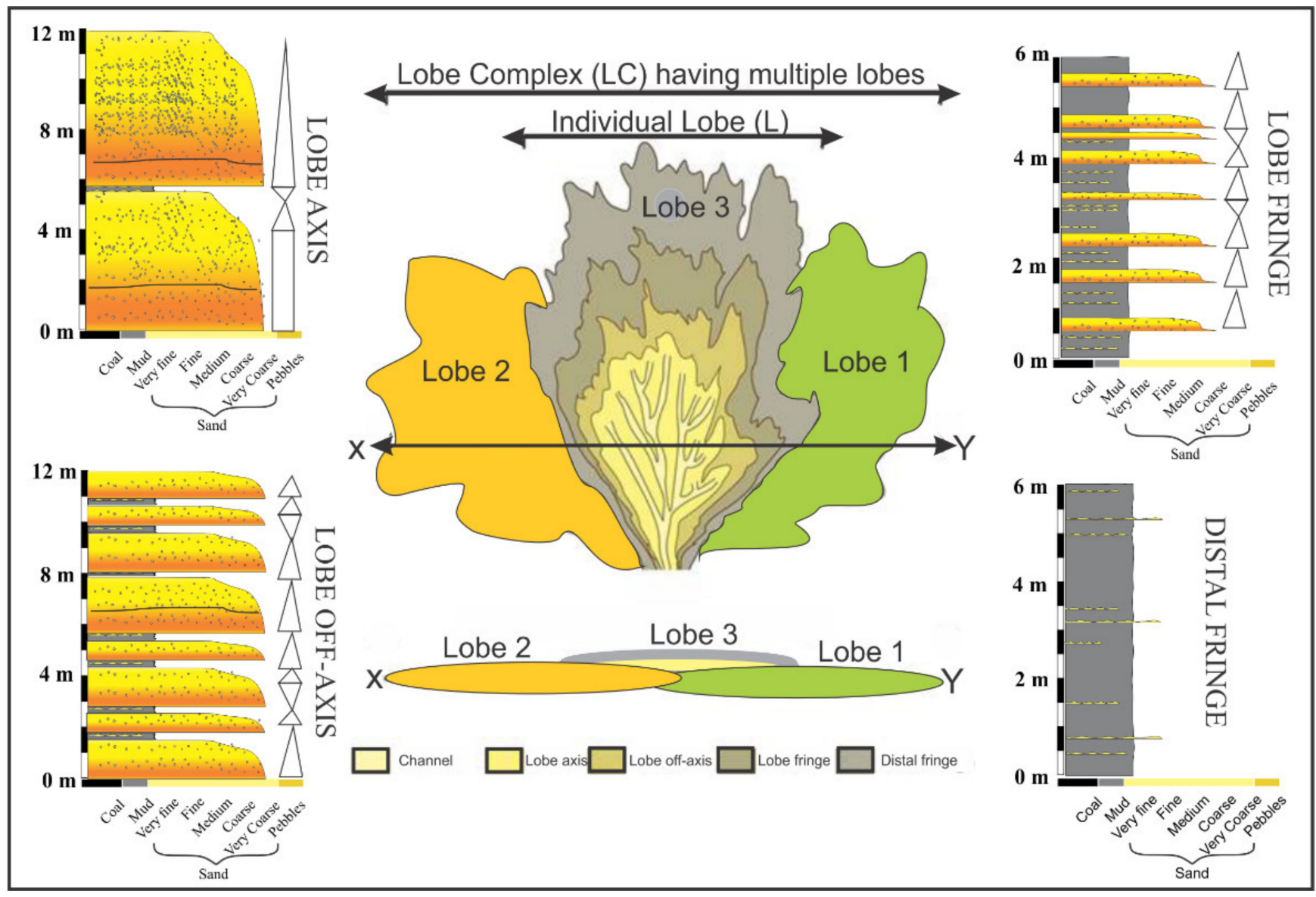

Figure 6. Lobe architecture and facies association of lobe settings. Thickening and thinning cycles are also marked on the bed scale for better understating of deep-marine lobe complex systems. L1 is the old event of lobe deposition, while L3 is the younger event partially overlapping the older lobe L1 and L2. Each lobe is further classified into axis (yellow color), off-axis (brown), fringe (brownish gray) and distal fringe (gray) from sand to shale or mud alterations [48].

\subsubsection{Facies Association 2 (FA2): Lobe Off-Axis}

The facies denote mainly sandstone units, which are medium- to thick-bedded and massive and where the average thickness was about $42.5 \mathrm{~cm}$, while most thickness values ranged from $10 \mathrm{~cm}$ to $250 \mathrm{~cm}$. There was a significant decrease in the sand-to-mud ratio and a lesser degree of amalgamation in the sand units. Hybrid event beds having greater sand bed thicknesses were also contained in this lobe off-axis [11] facies association. Sedimentary features like load casts and tool marks are common in this facies association. Some thick sand units are characterized by being massive or structureless, which is mostly associated with S1, S2 and S3 facies as well as with very rare S4 facies. Soft sediment deformation $\mathrm{S} 5$ is relatively common in this facies association. Amalgamated sand units also exist within this facies association. The abundant S3, S4 and Si1 facies represent the lobe off-axis deposition [50].

\subsubsection{Facies Association 3 (FA3): Lobe Fringe}

The lobe fringe is primarily characterized by muddy units, which comprise most of the percentage of sedimentary rocks. The main feature is rhythmic sandstone and mudstone units, which ranges in thickness from a few centimeters to tens of centimeters. The average thickness value was about $10.8 \mathrm{~cm}$, where the thicknesses of the bed units ranged from 1 to $18 \mathrm{~cm}$. The facies association included the S3, S4, Si1, Si2 and M facies. S1 facies are quite rare in this facies association. Furthermore, hybrid event beds $(\mathrm{H})$ with a lower sand thickness are associated with lobe fringe deposits [49]. The rock units have sharp contact 
and are relatively continuous laterally. A complete Bouma sequence (from Ta to Te) could be present, but typically, the basal massive sequence (Ta) is usually absent in the lobe fringe settings [26,94]. Thin-bedded sand and shale interbeds with a high fraction of mud and good lateral continuity are interpreted to be a part of lobe fringe deposits.

\subsubsection{Facies Association 4 (FA4): Distal Lobe or Interlobe}

All types of clastic units, like sandstones (thin-bedded fine to very fine-grained), siltstones and medium- to thick-bedded mudstones or shales were present in this facies association (Figure 7). However, mudstone or shale units mainly comprised this association. The thicknesses of most of sandstone units were less than $10 \mathrm{~cm}$, and the average value of the sand bed thickness was only $4.1 \mathrm{~cm}$. The thickness of the shale units (M facies) was significantly higher (more than $230 \mathrm{~cm}$ ) compared with other sandstone and siltstone facies. Owing to thin-bedded fine to very fine-grained deep-marine units having quite good lateral thicknesses and high fractions of thick mudstone or shale units, they were interpreted to be interlobe and lobe distal fringe facies associations. The slow hemipelagic to pelagic deposition was the result of low-density turbidity currents.

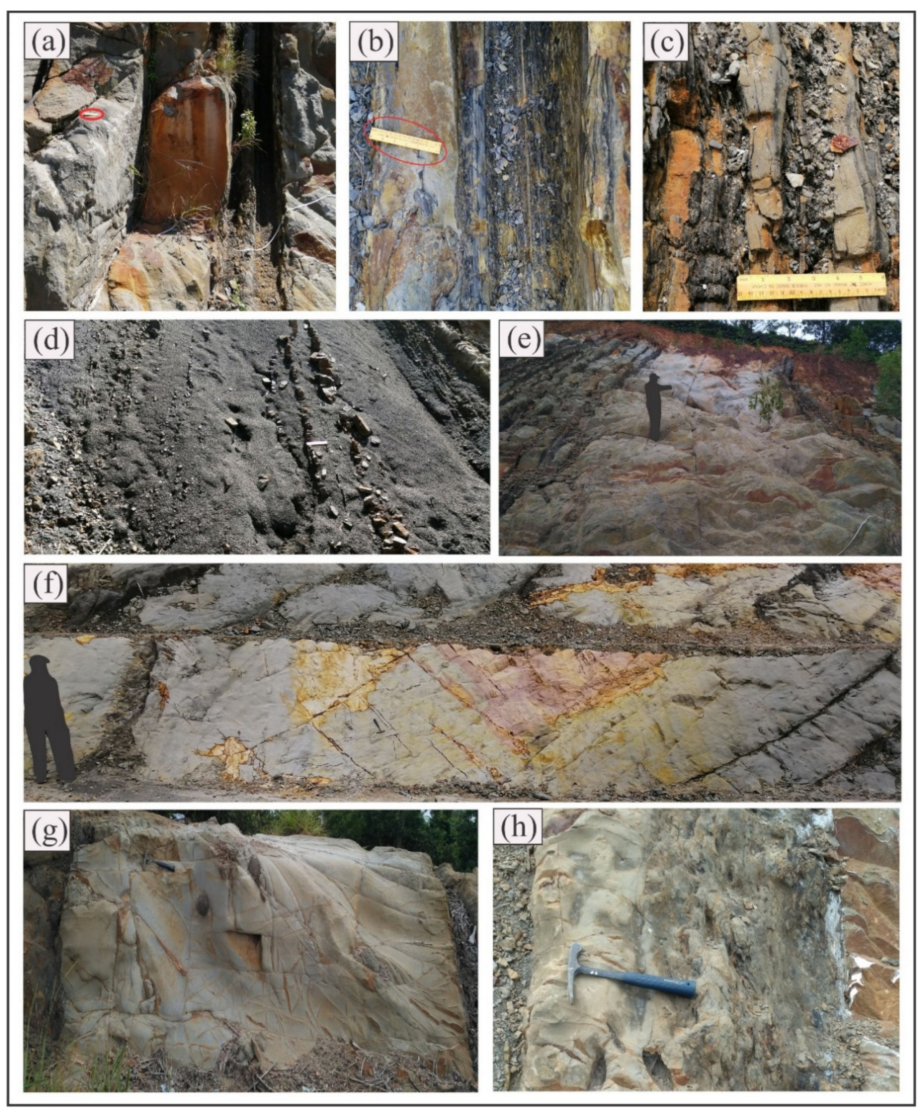

Figure 7. Facies associations. (a) Medium- to thick-bedded sandstone lobe fringe FA3 facies association in the Kampung Madpai section. (b) Medium- to thin-bedded sandstone of distal lobe fringe associated with the FA4 facies association in the Kampung Madpai outcrop. (c) Thin-bedded sandstone in the Jalan UMS road section, interpreted to be the distal lobe fringe to interlobe facies association FA4. (d) Mudstone facies interbedded with a thin sand unit, representative of distal lobe to interlobe FA4 settings in the Prima University Condo road outcrop. (e) Medium- to thick-bedded sandstone overlain by a massive sand unit of lobe axis FA2 in the Jalan UMS KFC outcrop. (f) Massive unit with amalgamation in the Jalan UMS road section, interpreted to be an FA1 facies association. (g) Massive sand with mudclasts and amalgamation in the Jalan UMS road section, belonging to the FA1 facies association. (h) Hybrid sand body in the Prima University road section, interpreted to be a lobe off-axis FA2 association. 


\section{Discussion}

\subsection{Thickening and Thinning Multiscale Trends}

Deep-marine sedimentary successions are characterized by multiscale thinning or thickening upward successions in exposed sections. These patterns were sometimes quite evident as we moved stratigraphically in the younging direction. Generally, lobe deposition is characterized by thickening or coarsening upward cycles, whereas channel setting is mostly linked with a thinning and fining upward sequence [17,95]. However, lobe progradation is considered a thickening (Figure 8) or coarsening sequence that has variations in the rate of sediment influx, resulting in a variety of sedimentary facies and their associations [14], while an individual thinning sequence may also be developed due to starvation of the deep-marine lobe system toward the lobe fringe or lateral lobes $[39,50]$. These thickening and thinning sand units represent unconfined lobe settings, and these thickening sandstone cycles are related to lobe axis and lobe off-axis facies associations $[11,15,88,96]$.

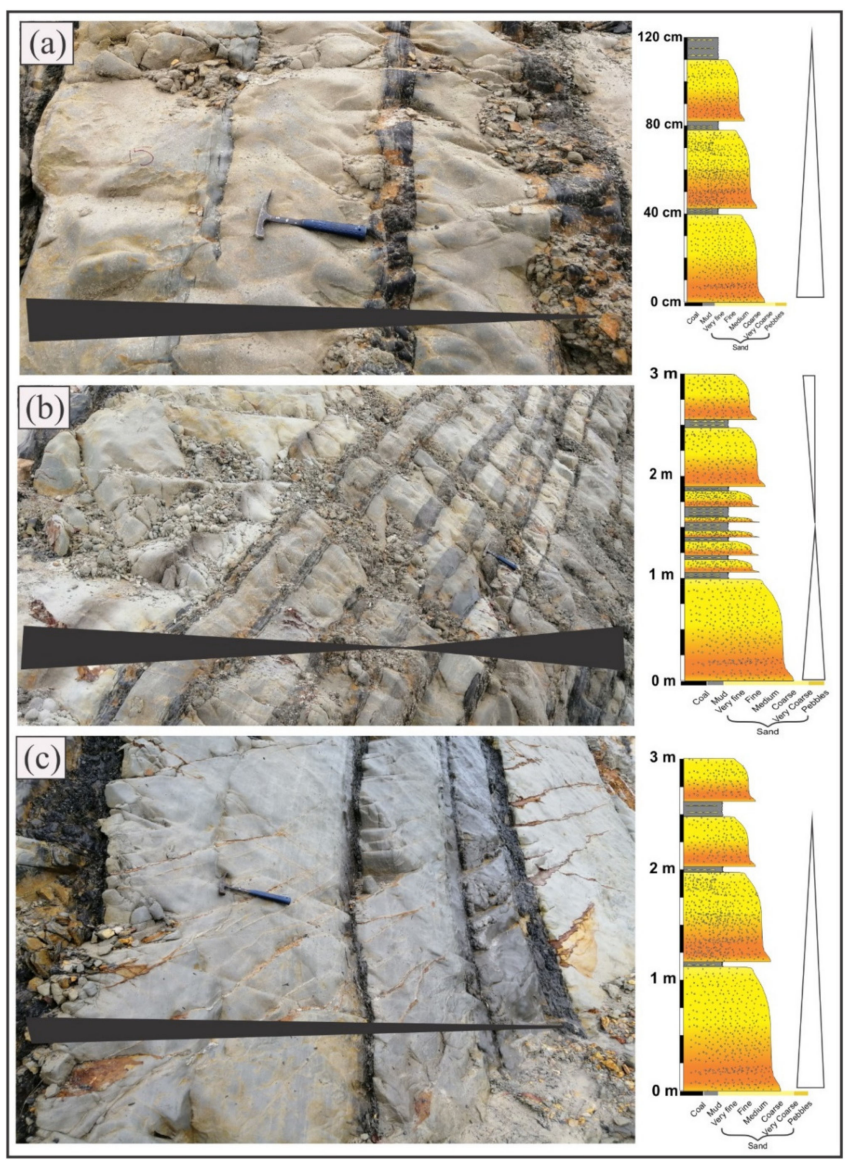

Figure 8. Thinning and thickening cycles in the Jalan UMS road section, where the vertical thicknesses of the cyclic patterns ranged only from 1.2 to $2.7 \mathrm{~m}$, which is indicative of a bed set or a lobe element. (a) Thinning pattern interpreted to be a lobe element. (b) Thinning and then thickening sequence, where each pattern represents the geometry of an individual lobe element. (c) Thinning trend with a vertical thickness of about $2.6 \mathrm{~m}$ in the set of beds.

A thinning upward sequence was observed in the Jalan UMS road section (Figure 8) because of lobe abandonment, while at one location, a thinning and then thickening cycle was observed in the outcrop, representing the cessation of a relatively older lobe and subsequently followed by the development of a newer, younger lobe [15,97]. Lobe thickness variation was significant in the Jalan UMS behind KFC section, where three cycles were observed. First was the thinning cycle, where the thicknesses of the individual sand units gradually decreased while the shale content increased as the stratigraphic order 
became younger (Figure 9). Another event of thinning and then thickening followed by two cycles of thickening was present, which were interpreted to be progradational lobe geometry. A thinning upward cycle was also marked in the Jalan Sulaman outcrop that was distinctive of lobe desertion.

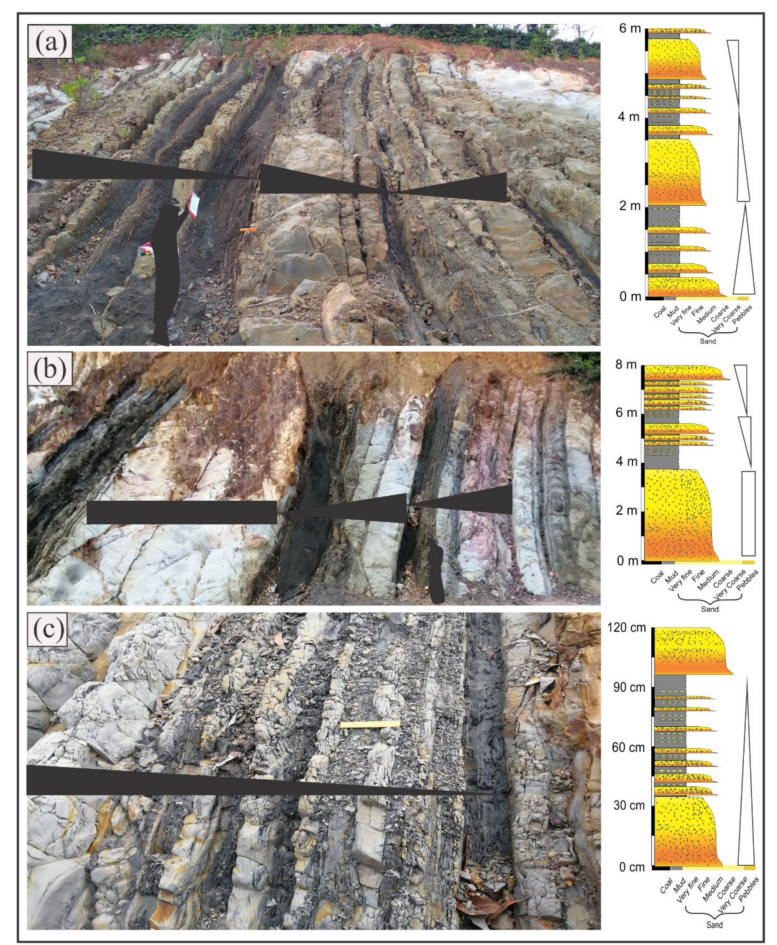

Figure 9. Thinning and thickening patterns (a) marked by three cycles-two thinning and one thickening - each of about a $2 \mathrm{~m}$ vertical thickness in the Jalan UMS behind KFC outcrop. (b) Massive sand unit overlain by two thickening trends in the Jalan UMS behind KFC outcrop. (c) One cycle of thinning with a vertical thickness of only $1 \mathrm{~m}$ in the Jalan Sulaman outcrop.

\subsection{Distribution of the Lobe Complex}

A submarine lobe system is a vital constituent of deep-marine fans. These lobes are characterized by geometries which are quite useful for interpreting the geological processes related to fan deposition [15]. Tectonically active regions are generally characterized by coarse sand units, representing the development of deep-marine fans having less than $10 \mathrm{~km}$ radial exposure on relatively higher slope angles, where a fan lobe system is frequently surrounded by shale cover [39].

These submarine fans are composed of numerous lobe complexes. The lobe architecture consists of a composite hierarchy from a smaller unit of a lobe element to a larger unit, which is termed as a composite lobe system or lobe complex set [22,24]. The lobe element is essentially comprised of one or more beds, with the thickness extending from a few decimeters to more than a meter [39]. The individual lithologies or beds collectively form an element of a lobe, while the group of lobe elements constitutes an individual lobe [15,24]. These lobes are characterized by interbedded sandstone and shale, with a collective range in size of several meters in thickness, combined to form a lobe complex (Figure 10) or also termed as stacked composite lobes [15,24]. Lobe components or sand-rich lobe complexes are separated from each other by a thick to massive hemipelagic to pelagic shale unit [22]. It is pertinent to mention here that each lobe component consists of one or more sandstone or shale beds, which enabled us to characterize the deep-marine deposits at a meter scale level. These high-resolution lithological observations could not be achieved by using seismic data. Hence, the study of lobe architecture at a lobe element scale caters to the idea of subseismic reservoir heterogeneity in submarine lobe-fan systems. 


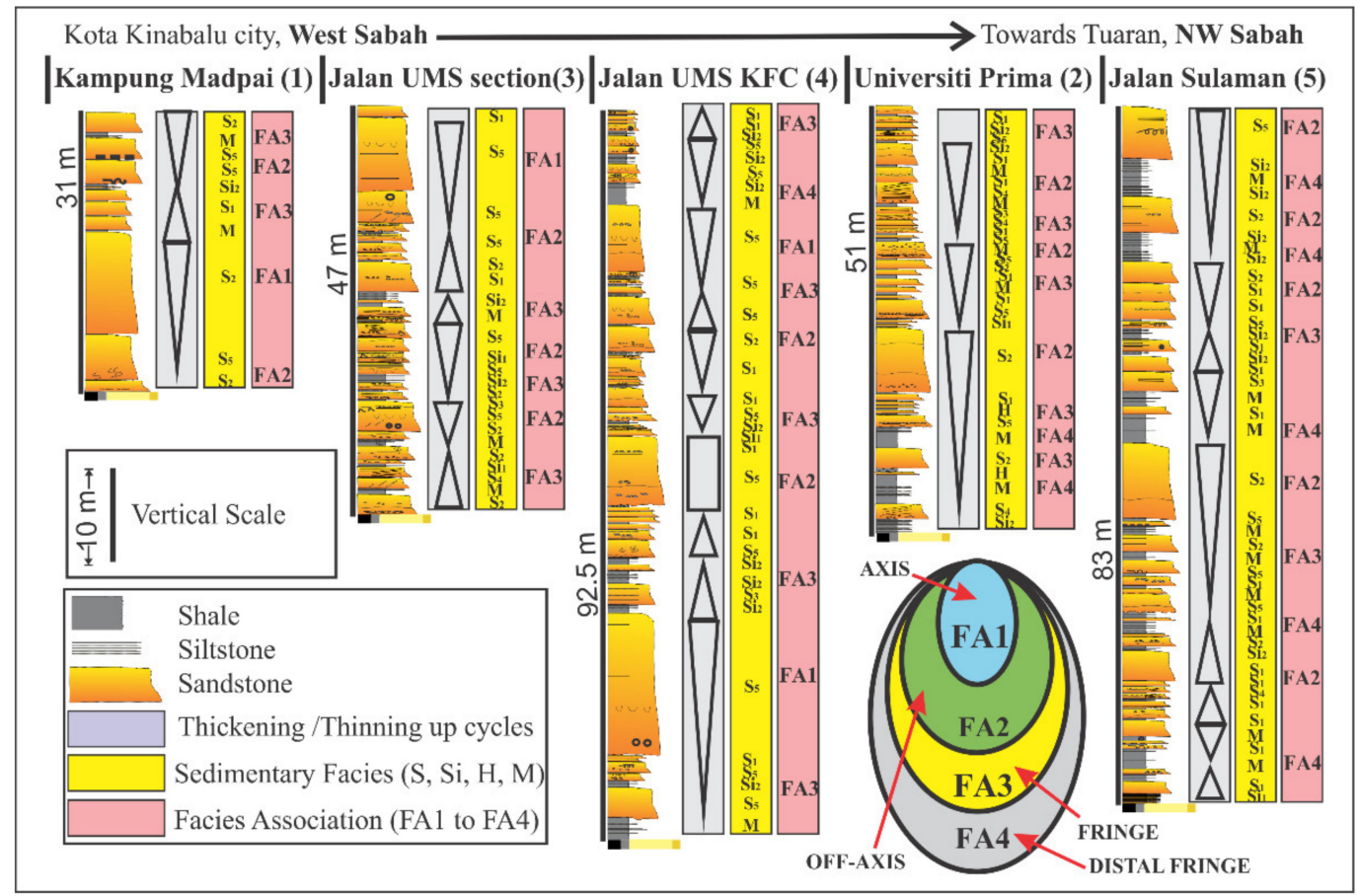

Figure 10. The distribution of facies, facies associations and thickening and thinning cycles in the exposed sections from Kota Kinabalu to Tuaran in northwest Sabah.

The results presented in this study reveal that there are multiple feeder channels in West Sabah's deposition, where the number of feeder channels and lobe complexes increased toward northwest Sabah. Multiple feeder channels resulted in three to four lobe complexes (LC), each of which was classified into individual lobes (L) and further into lobe elements (LE) (Figure 11). The thick to massive shale separated the individual lobe complexes.

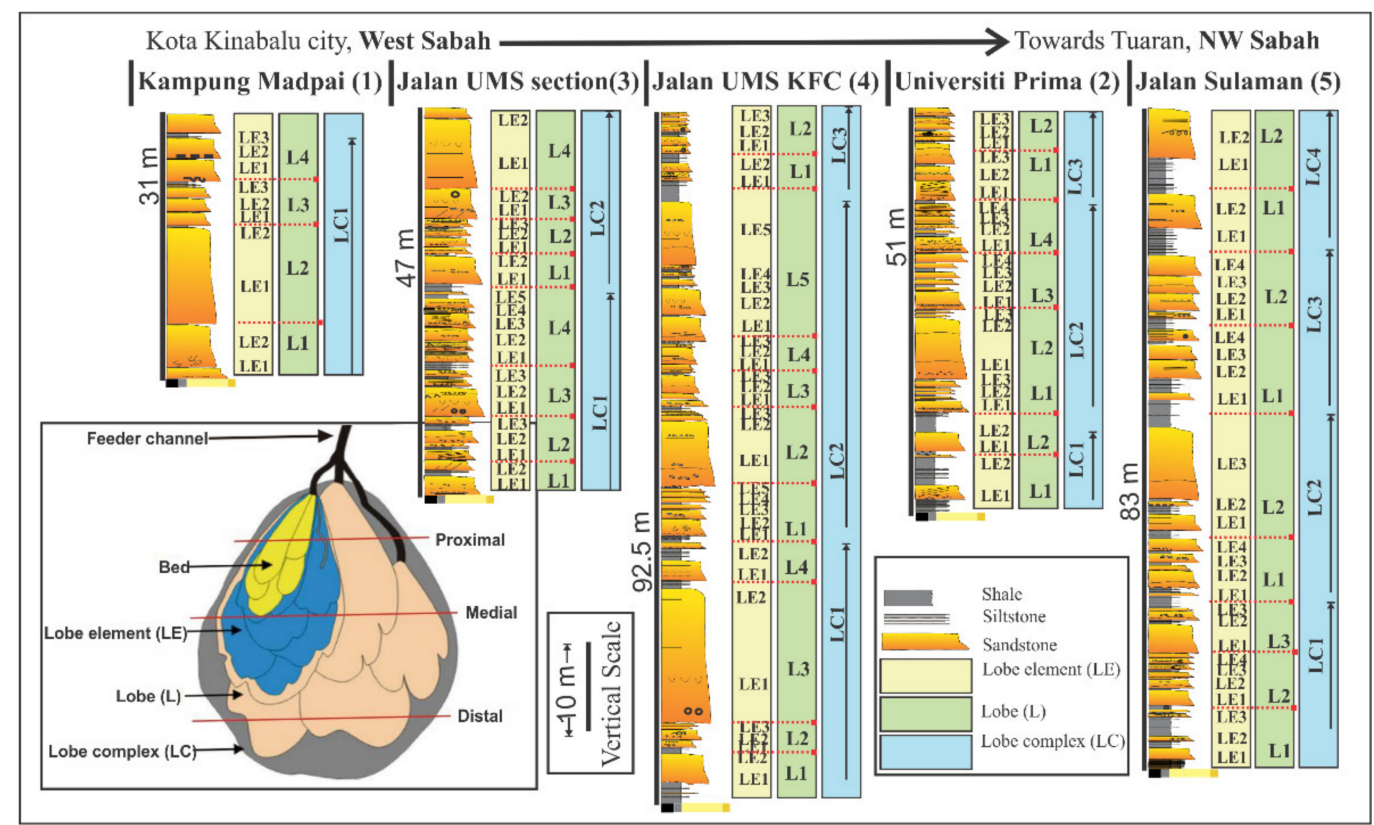

Figure 11. Distribution of lobe elements, individual lobes and lobe complexes in the studied outcrop sections [17,24]. 


\subsection{Submarine Fan-Lobe System}

The present study highlights that all the exposed sections were interpreted to be proximal to medial fan depositions, which were further classified into a lobe hierarchy. It incorporates the concept of a submarine fan and lobe system with respect to the multiscale analysis of sand-shale complexes in a deep marine environment. The individual lithological bed or bed set at a centimeter-to-meter scale is termed as a lobe element, which is the basic building block for the whole lobe-fan architecture. These lobe elements combine to form multimeter lobes, which are the cyclic or repetitive structures in a lobe complex or in a composite lobe system, which are tens of meters in thickness, while the composite lobes eventually constitute a smaller portion of the submarine fan at a scale of hundreds of meters. A complete fan system is present at a $\mathrm{km}$ scale over a large depositional area in a sedimentary basin.

\section{Conclusions}

The results highlight the facies analysis and facies association linked with the architectural elements of lobes in the submarine fan deposits of West Sabah. Based on these results, the following conclusions are drawn:

1. Although the West Crocker Formation is mainly considered to have sand-rich deposits (Crocker sands), the formation also contains massive shale and siltstone units. All types of sedimentary facies related to sandstone, siltstone and mudstone and could be termed as a sand-shale system. This variety of sediments shows more heterogeneity in lithological characteristics than previously thought;

2. The sedimentary facies were grouped into four facies associations, which were linked to the lobe architecture of deep-marine systems. These facies associations are discussed as components of individual lobes, namely the lobe axis, lobe off-axis, lobe fringe and distal fringe;

3. The thicknesses of individual sandstone units are helpful for interpreting several thickening and thinning multiscale sequences, which are characteristics of lobe progradation and lobe abandonment. These cycles of thickness variations represent the multiple tabular sand bodies of a lobe complex.

4. The deep-marine lobe deposits can be classified into beds or bed sets, which constitute the lobe elements. These lobe elements are grouped into individual lobes, which are broadly categorized into lobe complexes. These lobe element to lobe complex nomenclature can be identified on all exposed sections of West Sabah, where the individual thicknesses of lobe elements highly vary from as small as 1-3 $m$ up to a large thickness of 8-10 $\mathrm{m}$ in the studied sections having multiscale sand-shale complex.

5. The West Crocker Formation is interpreted as a lobe complex set in which multiple lobe complexes are present, with their individual lobes and lobe elements based on bed-to-bed sedimentary analysis and supporting the multiscale modeling of deep ocean sediments.

6. The lobe complex sets are more developed in northwest Sabah, while West Sabah has a lower number of lobe complexes. This distribution of lobe complexes also verifies that the paleocurrent direction is mainly from the south to the north, where the feeder channels form multiple lobe complexes in northwest Sabah.

7. The detailed facies and lobe architecture depict reservoir heterogeneities in deepmarine siliciclastic rocks, which are usually interpreted as single homogeneous sand units by seismic data. Hence, the present study highlights the subseismic lithological complexities in deep-marine depositional settings.

8. The alternate lobe off-axis and lobe axis distributions, interpreted as unconfined lobe settings, could be applicable for several unconfined deep-marine sedimentary successions around the globe which are potential sites of exploration of natural resources. 
Author Contributions: Conceptualization, M.J., N.A.S. and A.H.B.A.R.; methodology, M.J., N.A., M.S.B.I. and N.A.I; software, M.J., M.U., A.H.B.A.R., and Z.G.; validation, M.J., N.A.S., A.H.B.A.R., and N.A.I.; formal analysis, M.J., Q.S.I. and M.U.; investigation, M.J., N.A.S. and Z.G.; resources, N.A.S., A.H.B.A.R. and N.A.I.; data curation, M.J. and N.A.; writing-original draft preparation, M.J.; writing-review and editing, N.A.S., A.H.B.A.R. and M.U.; visualization, M.J., M.U. and N.A.; supervision, N.A.S., M.S.B.I. and A.H.B.A.R.; project administration, N.A.I. and N.A.; funding acquisition, N.A.S., A.H.B.A.R. and N.A.I. All authors have read and agreed to the published version of the manuscript.

Funding: This research was funded by the Petroleum Research Fund (PRF) cost number 0153AB-A33, awarded to Eswaran Padmanabhan and the Fundamental Research Grant of the Ministry of Higher Education (MoHE) Malaysia (project ID 16880, reference code FRGS/1/2019/STG09/UTP/03/1) for data analysis and detailed fieldwork. The first phase of geological field was supported by Yayasan UTP Malaysia (YUTP) grant number 015LC-017, awarded to Noor Azahar Ibrahim.

Institutional Review Board Statement: Not applicable.

Informed Consent Statement: Not applicable.

Data Availability Statement: The dataset would be available from the first author, if required for reference purposes.

Acknowledgments: The authors are thankful to the faculty and staff of the Department of Geoscience at UTP Malaysia for their support in arranging the geological fieldwork. The comments and feedback from anonymous reviewers improved the manuscript.

Conflicts of Interest: The authors declare no conflict of interest.

\section{References}

1. Lorentzen, S.; Augustsson, C.; Jahren, J.; Nystuen, J.P.; Schovsbo, N.H. Tectonic, sedimentary and diagenetic controls on sediment maturity of lower Cambrian quartz arenite from southwestern Baltica. Basin Res. 2019, 31, 1098-1120. [CrossRef]

2. Covault, J.A.; Graham, S.A. Submarine fans at all sea-level stands: Tectono-morphologic and climatic controls on terrigenous sediment delivery to the deep sea. Geology 2010, 38, 939-942. [CrossRef]

3. Pickering, K.T.; Bayliss, N.J. Deconvolving tectono-climatic signals in deep-marine siliciclastics, Eocene Ainsa basin, Spanish Pyrenees: Seesaw tectonics versus eustasy. Geology 2009, 37, 203-206. [CrossRef]

4. Kontakiotis, G.; Karakitsios, V.; Cornée, J.-J.; Moissette, P.; Zarkogiannis, S.D.; Pasadakis, N.; Koskeridou, E.; Manoutsoglou, E.; Drinia, H.; Antonarakou, A. Preliminary results based on geochemical sedimentary constraints on the hydrocarbon potential and depositional environment of a Messinian sub-salt mixed siliciclastic-carbonate succession onshore Crete (Plouti section, eastern Mediterranean). Mediterr. Geosci. Rev. 2020, 2, 247-265. [CrossRef]

5. Leila, M.; Moscariello, A.; Kora, M.; Mohamed, A.; Samankassou, E. Sedimentology and reservoir quality of a Messinian mixed siliciclastic-carbonate succession, onshore Nile Delta, Egypt. Mar. Pet. Geol. 2020, 112, 104076. [CrossRef]

6. Richards, M.; Bowman, M.; Reading, H. Submarine-fan systems i: Characterization and stratigraphic prediction. Mar. Pet. Geol. 1998, 15, 689-717. [CrossRef]

7. Zhang, J.; Wu, S.; Hu, G.; Fan, T.-e.; Yu, B.; Lin, P.; Jiang, S. Sea-level control on the submarine fan architecture in a deepwater sequence of the Niger Delta Basin. Mar. Pet. Geol. 2018, 94, 179-197. [CrossRef]

8. Zhang, J.-J.; Wu, S.-H.; Fan, T.-E.; Fan, H.-J.; Jiang, L.; Chen, C.; Wu, Q.-Y.; Lin, P. Research on the architecture of submarine-fan lobes in the Niger Delta Basin, offshore West Africa. J. Palaeogeogr. 2016, 5, 185-204. [CrossRef]

9. Kane, I.A.; Pontén, A.S. Submarine transitional flow deposits in the Paleogene Gulf of Mexico. Geology 2012, 40, 1119-1122. [CrossRef]

10. Liu, F.; Zhu, X.; Li, Y.; Xue, M.; Sun, J. Sedimentary facies analysis and depositional model of gravity-flow deposits of the Yanchang Formation, southwestern Ordos Basin, NW China. Aust. J. Earth Sci. 2016, 63, 885-902. [CrossRef]

11. Mueller, P.; Patacci, M.; Di Giulio, A. Hybrid event beds in the proximal to distal extensive lobe domain of the coarse-grained and sand-rich Bordighera turbidite system (NW Italy). Mar. Pet. Geol. 2017, 86, 908-931. [CrossRef]

12. Mulder, T.; Alexander, J. The physical character of subaqueous sedimentary density flow and their deposits. Sedimentology 2001, 48, 269-299. [CrossRef]

13. Palozzi, J.; Pantopoulos, G.; Maravelis, A.G.; Nordsvan, A.; Zelilidis, A. Sedimentological analysis and bed thickness statistics from a Carboniferous deep-water channel-levee complex: Myall Trough, SE Australia. Sediment. Geol. 2018, 364, 160-179. [CrossRef]

14. Starek, D.; Fuksi, T. Distal turbidite fan/lobe succession of the Late Oligocene Zuberec Fm.-architecture and hierarchy (Central Western Carpathians, Orava-Podhale basin). Open Geosci. 2017, 9, 385-406. [CrossRef]

15. Macdonald, H.A.; Peakall, J.; Wignall, P.B.; Best, J. Sedimentation in deep-sea lobe-elements: Implications for the origin of thickening-upward sequences. J. Geol. Soc. 2011, 168, 319-332. [CrossRef] 
16. Mulder, T.; Etienne, S. Lobes in deep-sea turbidite systems: State of the art. Sediment. Geol. 2010, 229, 75-80. [CrossRef]

17. Prélat, A.; Hodgson, D.; Flint, S. Evolution, architecture and hierarchy of distributary deep-water deposits: A high-resolution outcrop investigation from the Permian Karoo Basin, South Africa. Sedimentology 2009, 56, 2132-2154. [CrossRef]

18. Lowe, D.R.; Guy, M. Slurry-flow deposits in the Britannia Formation (Lower Cretaceous), North Sea: A new perspective on the turbidity current and debris flow problem. Sedimentology 2000, 47, 31-70. [CrossRef]

19. Spychala, Y.T.; Hodgson, D.M.; Prélat, A.; Kane, I.A.; Flint, S.S.; Mountney, N.P. Frontal and lateral submarine lobe fringes: Comparing sedimentary facies, architecture and flow processes. J. Sediment. Res. 2017, 87, 75-96. [CrossRef]

20. Bell, D.; Kane, I.A.; Pontén, A.S.M.; Flint, S.S.; Hodgson, D.M.; Barrett, B.J. Spatial variability in depositional reservoir quality of deep-water channel-fill and lobe deposits. Mar. Pet. Geol. 2018, 98, 97-115. [CrossRef]

21. Clare, M.A.; Talling, P.J.; Challenor, P.; Malgesini, G.; Hunt, J. Distal turbidites reveal a common distribution for large $\left(>0.1 \mathrm{~km}^{3}\right)$ submarine landslide recurrence. Geology 2014, 42, 263-266. [CrossRef]

22. Zhang, L.-F.; Dong, D.-Z. Thickening-upward cycles in deep-marine and deep-lacustrine turbidite lobes: Examples from the Clare Basin and the Ordos Basin. J. Palaeogeogr. 2020, 9, 1-16. [CrossRef]

23. Spychala, Y.T.; Hodgson, D.M.; Lee, D.R. Autogenic controls on hybrid bed distribution in submarine lobe complexes. Mar. Pet. Geol. 2017, 88, 1078-1093. [CrossRef]

24. Zhang, L.-F.; Pan, M.; Li, Z.-L. 3D modeling of deepwater turbidite lobes: A review of the research status and progress. Pet. Sci. 2020, 17, 317-333. [CrossRef]

25. Mutti, E.; Bernoulli, D.; Lucchi, F.R.; Tinterri, R. Turbidites and turbidity currents from Alpine 'flysch'to the exploration of continental margins. Sedimentology 2009, 56, 267-318. [CrossRef]

26. Peakall, J.; Best, J.; Baas, J.H.; Hodgson, D.M.; Clare, M.A.; Talling, P.J.; Dorrell, R.M.; Lee, D.R. An integrated process-based model of flutes and tool marks in deep-water environments: Implications for palaeohydraulics, the Bouma sequence and hybrid event beds. Sedimentology 2020, 67, 1601-1666. [CrossRef]

27. Zakaria, A.A.; Johnson, H.D.; Jackson, C.A.L.; Tongkul, F. Sedimentary facies analysis and depositional model of the Palaeogene West Crocker submarine fan system, NW Borneo. J. Asian Earth Sci. 2013, 76, 283-300. [CrossRef]

28. Jackson, C.A.L.; Zakaria, A.A.; Johnson, H.D.; Tongkul, F.; Crevello, P.D. Sedimentology, stratigraphic occurrence and origin of linked debrites in the West Crocker Formation (Oligo-Miocene), Sabah, NW Borneo. Mar. Pet. Geol. 2009, 26, 1957-1973. [CrossRef]

29. Jamil, M.; Abd Rahman, A.H.; Siddiqui, N.A.; Ibrahim, N.A.; Ahmed, N. A contemporary review of sedimentological and stratigraphic framework of the Late Paleogene deep marine sedimentary successions of West Sabah, North-West Borneo. Bull. Geol. Soc. Malays. 2020, 69, 53-65. [CrossRef]

30. Lambiase, J.J.; Tzong, T.Y.; William, A.G.; Bidgood, M.D.; Brenac, P.; Cullen, A.B. The West Crocker formation of northwest Borneo: A Paleogene accretionary prism. Spec. Pap. Geol. Soc. Am. 2008, 436, 171-184.

31. Usman, M.; Siddiqui, N.A.; Mathew, M.; Zhang, S.; El-Ghali, M.A.K.; Ramkumar, M.; Jamil, M.; Zhang, Y. Linking the influence of diagenetic properties and clay texture on reservoir quality in sandstones from NW Borneo. Mar. Pet. Geol. 2020, 120, 104509. [CrossRef]

32. Usman, M.; Siddiqui, N.A.; Zhang, S.; Ramkumar, M.; Mathew, M.; Sautter, B.; Beg, M.A. Ichnofacies and sedimentary structures: A passive relationship with permeability of a sandstone reservoir from NW Borneo. J. Asian Earth Sci. 2020, $192,103992$. [CrossRef]

33. Hall, R.; Nichols, G. Cenozoic sedimentation and tectonics in Borneo: Climatic influences on orogenesis. Geol. Soc. Lond. Spec. Publ. 2002, 191, 5-22. [CrossRef]

34. Banerjee, A.; Ahmed Salim, A.M. Stratigraphic evolution of deep-water Dangerous Grounds in the South China Sea, NW Sabah Platform Region, Malaysia. J. Pet. Sci. Eng. 2021, 201, 108434. [CrossRef]

35. Cullis, S.; Patacci, M.; Colombera, L.; Bührig, L.; McCaffrey, W.D. A database solution for the quantitative characterisation and comparison of deep-marine siliciclastic depositional systems. Mar. Pet. Geol. 2019, 102, 321-339. [CrossRef]

36. Mayall, M.; Jones, E.; Casey, M. Turbidite channel reservoirs-Key elements in facies prediction and effective development. Mar. Pet. Geol. 2006, 23, 821-841. [CrossRef]

37. Prather, B.E. Controls on reservoir distribution, architecture and stratigraphic trapping in slope settings. Mar. Pet. Geol. 2003, 20, 529-545. [CrossRef]

38. Zhang, L.; Pan, M.; Wang, H. Deepwater Turbidite Lobe Deposits: A Review of the Research Frontiers. Acta Geol. Sin. Engl. Ed. 2017, 91, 283-300. [CrossRef]

39. Postma, G.; Kleverlaan, K. Supercritical flows and their control on the architecture and facies of small-radius sand-rich fan lobes. Sediment. Geol. 2018, 364, 53-70. [CrossRef]

40. Hodgson, D.M.; Kane, I.A.; Flint, S.S.; Brunt, R.L.; Ortiz-Karpf, A. Time-transgressive confinement on the slope and the progradation of basin-floor fans: Implications for the sequence stratigraphy of deep-water deposits. J. Sediment. Res. 2016, 86, 73-86. [CrossRef]

41. Rodríguez-Cañero, R.; Jabaloy-Sánchez, A.; Navas-Parejo, P.; Martín-Algarra, A. Linking Palaeozoic palaeogeography of the Betic Cordillera to the Variscan Iberian Massif: New insight through the first conodonts of the Nevado-Filábride Complex. Int. J. Earth Sci. 2018, 107, 1791-1806. [CrossRef]

42. Reading, H.G. Clastic facies models, a personal perspective. Bull. Geol. Soc. Den. 2001, 48, 101-115. 
43. Fonnesu, M.; Haughton, P.; Felletti, F.; McCaffrey, W. Short length-scale variability of hybrid event beds and its applied significance. Mar. Pet. Geol. 2015, 67, 583-603. [CrossRef]

44. Yang, T.; Cao, Y.; Friis, H.; Liu, K.; Wang, Y. Origin and evolution processes of hybrid event beds in the Lower Cretaceous of the Lingshan Island, Eastern China. Aust. J. Earth Sci. 2018, 65, 517-534. [CrossRef]

45. Kane, I.A.; Pontén, A.S.M.; Vangdal, B.; Eggenhuisen, J.T.; Hodgson, D.M.; Spychala, Y.T. The stratigraphic record and processes of turbidity current transformation across deep-marine lobes. Sedimentology 2017, 64, 1236-1273. [CrossRef]

46. Doughty-Jones, G.; Mayall, M.; Lonergan, L. Stratigraphy, facies, and evolution of deep-water lobe complexes within a saltcontrolled intraslope minibasin. Aapg Bull. 2017, 101, 1879-1904. [CrossRef]

47. Groenenberg, R.M.; Hodgson, D.M.; Prelat, A.; Luthi, S.M.; Flint, S.S. Flow-deposit interaction in submarine lobes: Insights from outcrop observations and realizations of a process-based numerical model. J. Sediment. Res. 2010, 80, 252-267. [CrossRef]

48. Hansen, L.A.S.; Hodgson, D.M.; Pontén, A.; Bell, D.; Flint, S. Quantification of Basin-Floor Fan Pinchouts: Examples From the Karoo Basin, South Africa. Front. Earth Sci. 2019, 7, 12. [CrossRef]

49. Kuswandaru, G.Y.; Amir Hassan, M.H.; Matenco, L.C.; Taib, N.I.; Mustapha, K.A. Turbidite, debrite, and hybrid event beds in submarine lobe deposits of the Palaeocene to middle Eocene Kapit and Pelagus members, Belaga Formation, Sarawak, Malaysia. Geol. J. 2019, 54, 3421-3437. [CrossRef]

50. Prelat, A.; Hodgson, D. The full range of turbidite bed thickness patterns in submarine lobes: Controls and implications. J. Geol. Soc. 2013, 170, 209-214. [CrossRef]

51. Hall, R. Contraction and extension in northern Borneo driven by subduction rollback. J. Asian Earth Sci. 2013, 76, 399-411. [CrossRef]

52. Hazebroek, H.P.; Tan, D.N. Tertiary tectonic evolution of the NW Sabah continental margin. Bull. Geol. Soc. Malays. 1993, 33, 195-210. [CrossRef]

53. Siddiqui, N.A.; Ramkumar, M.; Rahman, A.H.A.; Mathew, M.J.; Santosh, M.; Sum, C.W.; Menier, D. High resolution facies architecture and digital outcrop modeling of the Sandakan formation sandstone reservoir, Borneo: Implications for reservoir characterization and flow simulation. Geosci. Front. 2019, 10, 957-971. [CrossRef]

54. Siddiqui, N.A.; Mathew, M.J.; Ramkumar, M.; Sautter, B.; Usman, M.; Abdul Rahman, A.H.; El-Ghali, M.A.K.; Menier, D.; Shiqi, Z.; Sum, C.W. Sedimentological characterization, petrophysical properties and reservoir quality assessment of the onshore Sandakan Formation, Borneo. J. Pet. Sci. Eng. 2020, 186, 106771. [CrossRef]

55. Wang, P.C.; Li, S.Z.; Guo, L.L.; Jiang, S.H.; Somerville, I.D.; Zhao, S.J.; Zhu, B.D.; Chen, J.; Dai, L.M.; Suo, Y.H.; et al. Mesozoic and Cenozoic accretionary orogenic processes in Borneo and their mechanisms. Geol. J. 2016, 51, 464-489. [CrossRef]

56. Chang, S.-P.; Jamaludin, S.N.F.; Pubellier, M.; Zainuddin, N.M.; Choong, C.-M. Collision, mélange and circular basins in north Borneo: A genetic link? J. Asian Earth Sci. 2019, 181, 103895. [CrossRef]

57. Clennell, B. Far-field and gravity tectonics in Miocene basins of Sabah, Malaysia. Geol. Soc. Lond. Spec. Publ. 1996, 106, 307-320. [CrossRef]

58. Hutchison, C.S. Geology of North-West Borneo: Sarawak, Brunei and Sabah; Elsevier: Amsterdam, The Netherlands, 2005 ; pp. 61-241.

59. Morley, C. Major unconformities/termination of extension events and associated surfaces in the South China Seas: Review and implications for tectonic development. J. Asian Earth Sci. 2016, 120, 62-86. [CrossRef]

60. Rangin, C.; Bellon, H.; Benard, F.; Letouzey, J.; Muller, C.; Sanudin, T. Neogene arc-continent collision in Sabah, northern Borneo (Malaysia). Tectonophysics 1990, 183, 305-319. [CrossRef]

61. Madon, M.; Kessler, F.L.; Jong, J.; Amin, M.K.A. "Fractured basement" play in the Sabah Basin?-the Crocker and Kudat formations as hydrocarbon reservoirs and their risk factors. Bull. Geol. Soc. Malays. 2020, 69, 157-171. [CrossRef]

62. Lunt, P. A new view of integrating stratigraphic and tectonic analysis in South China Sea and north Borneo basins. J. Asian Earth Sci. 2019, 177, 220-239. [CrossRef]

63. Hesse, S.; Back, S.; Franke, D. The deep-water fold-and-thrust belt offshore NW Borneo: Gravity-driven versus basement-driven shortening. Geol. Soc. Am. Bull. 2009, 121, 939-953. [CrossRef]

64. Mustafar, M.A.; Simons, W.J.; Tongkul, F.; Satirapod, C.; Omar, K.M.; Visser, P.N. Quantifying deformation in North Borneo with GPS. J. Geod. 2017, 91, 1241-1259. [CrossRef]

65. Madon, M. Sand injectites in the West Crocker Formation, Kota Kinabalu, Sabah. Bull. Geol. Soc. Malays. 2020, 69, 11-26. [CrossRef]

66. Leong, K. Geological setting of Sabah. In The Petroleum Geology and Resources of Malaysia; Petroliam Nasional Berhad (PETRONAS): Kuala Lumpur, Malaysia, 1999; pp. 473-497.

67. Leong, T.B.G.; Tahir, S.H.; Asis, J. Stratigraphy of Paleogene Sequences in Weston-Sipitang, Sabah. Geol. Behav. 2018, 2, 1-4.

68. Jackson, C.A.; Johnson, H.D. Sustained turbidity currents and their interaction with debrite-related topography; Labuan Island, offshore NW Borneo, Malaysia. Sediment. Geol. 2009, 219, 77-96. [CrossRef]

69. Jamil, M.; Rahman, A.H.A.; Siddiqui, N.A.; Ahmed, N. Deep marine Paleogene sedimentary sequence of West Sabah: Contemporary opinions and ambiguities. War. Geol. 2019, 45, 198-200.

70. Van Hattum, M.W.; Hall, R.; Pickard, A.L.; Nichols, G.J. Southeast Asian sediments not from Asia: Provenance and geochronology of north Borneo sandstones. Geology 2006, 34, 589-592. [CrossRef]

71. Van Hattum, M.W.A.; Hall, R.; Pickard, A.L.; Nichols, G.J. Provenance and geochronology of Cenozoic sandstones of northern Borneo. J. Asian Earth Sci. 2013, 76, 266-282. [CrossRef] 
72. William, A.G.; Lambiase, J.J.; Back, S.; Jamiran, M.K. Sedimentology of the Jalan Salaiman and Bukit Melinsung outcrops, western Sabah: Is the West Crocker Formation an analogue for Neogene turbidites offshore? Bull. Geol. Soc. Malays. 2003, 47, 63-75. [CrossRef]

73. Stow, D.; Smillie, Z. Distinguishing between Deep-Water Sediment Facies: Turbidites, Contourites and Hemipelagites. Geosciences 2020, 10, 68. [CrossRef]

74. Koç-Taşgın, C.; Altun, F. Soft-sediment deformation: Deep-water slope deposits of a back-arc basin (middle Eocene-Oligocene Kırkgeçit Formation, Elazı̆̆ Basin), Eastern Turkey. Arab. J. Geosci. 2019, 12, 773. [CrossRef]

75. Hodgson, D.M.; Flint, S.S.; Hodgetts, D.; Drinkwater, N.J.; Johannessen, E.P.; Luthi, S.M. Stratigraphic Evolution of Fine-Grained Submarine Fan Systems, Tanqua Depocenter, Karoo Basin, South Africa. J. Sediment. Res. 2006, 76, 20-40. [CrossRef]

76. Johnson, S.D.; Flint, S.; Hinds, D.; De Ville Wickens, H. Anatomy, geometry and sequence stratigraphy of basin floor to slope turbidite systems, Tanqua Karoo, South Africa. Sedimentology 2001, 48, 987-1023. [CrossRef]

77. Hodgson, D.M. Distribution and origin of hybrid beds in sand-rich submarine fans of the Tanqua depocentre, Karoo Basin, South Africa. Mar. Pet. Geol. 2009, 26, 1940-1956. [CrossRef]

78. Bouma, A.H. Sedimentology of some flysch deposits. In Agraphic Approach Facies Interpret; Elsevier: Amsterdam, The Netherlands, 1962; Volume 168.

79. Mutti, E. Turbidite Sandstones; AGIP, Istituto di Geologia, Università di Parma: San Donato Milanese, Italy, 1992.

80. Lowe, D.R. Sediment gravity flows: II. Depositional models with special reference to the deposits of high-density turbidity currents. J. Sediment. Petrol. 1982, 52, 279-297.

81. Mutti, E.; Tinterri, R.; Benevelli, G.; Biase, D.d.; Cavanna, G. Deltaic, mixed and turbidite sedimentation of ancient foreland basins. Mar. Pet. Geol. 2003, 20, 733-755. [CrossRef]

82. Leclair, S.F.; Arnott, R.W.C. Parallel Lamination Formed by High-Density Turbidity Currents. J. Sediment. Res. 2005, 75, 1-5. [CrossRef]

83. Postma, G.; Kleverlaan, K.; Cartigny, M.J.B. Recognition of cyclic steps in sandy and gravelly turbidite sequences, and consequences for the Bouma facies model. Sedimentology 2014, 61, 2268-2290. [CrossRef]

84. Jobe, Z.R.; Lowe, D.R.; Morris, W.R. Climbing-ripple successions in turbidite systems: Depositional environments, sedimentation rates and accumulation times. Sedimentology 2012, 59, 867-898. [CrossRef]

85. Owen, G. Deformation processes in unconsolidated sands. Geol. Soc. Lond. Spec. Publ. 1987, 29, 11-24. [CrossRef]

86. Haughton, P.D.W.; Barker, S.P.; McCaffrey, W.D. 'Linked' debrites in sand-rich turbidite systems-origin and significance. Sedimentology 2003, 50, 459-482. [CrossRef]

87. Haughton, P.; Davis, C.; McCaffrey, W.; Barker, S. Hybrid sediment gravity flow deposits-Classification, origin and significance. Mar. Pet. Geol. 2009, 26, 1900-1918. [CrossRef]

88. Terlaky, V.; Arnott, R.W.C. Matrix-rich and associated matrix-poor sandstones: Avulsion splays in slope and basin-floor strata. Sedimentology 2014, 61, 1175-1197. [CrossRef]

89. Stow, D. Deep-sea clastics: Where are we and where are we going? Geol. Soc. Lond. Spec. Publ. 1985, 18, 67-93. [CrossRef]

90. Stow, D.A.V.; Shanmugam, G. Sequence of structures in fine-grained turbidites: Comparison of recent deep-sea and ancient flysch sediments. Sediment. Geol. 1980, 25, 23-42. [CrossRef]

91. Van Daele, M.; Meyer, I.; Moernaut, J.; De Decker, S.; Verschuren, D.; De Batist, M. A revised classification and terminology for stacked and amalgamated turbidites in environments dominated by (hemi)pelagic sedimentation. Sediment. Geol. 2017, 357, 72-82. [CrossRef]

92. Bábek, O.; Mikuláš, R.; Zapletal, J.; Lehotský, T. Combined tectonic-sediment supply-driven cycles in a Lower Carboniferous deep-marine foreland basin, Moravice Formation, Czech Republic. Int. J. Earth Sci. 2004, 93, 241-261. [CrossRef]

93. Shi, G.; Huang, C.; Jiang, S.; Wang, H.; Liang, C.; Yue, J.; Song, G. Late Paleozoic gravity flow depositional systems in the Mandula Basin of the Solonker Belt, Inner Mongolia, China: Towards a volcanic-associated submarine environment. Int. J. Earth Sci. 2020, 109, 1613-1637. [CrossRef]

94. Pickering, K.T. Two types of outer fan lobe sequence, from the late Precambrian Kongsfjord Formation submarine fan, Finnmark, North Norway. J. Sediment. Res. 1981, 51, 1277-1286. [CrossRef]

95. Chakraborty, P.P.; Mukhopadhyay, B.; Pal, T.; Dutta Gupta, T. Statistical appraisal of bed thickness patterns in turbidite successions, Andaman Flysch Group, Andaman Islands, India. J. Asian Earth Sci. 2002, 21, 189-196. [CrossRef]

96. Terlaky, V.; Arnott, R.W.C. The Control Of Terminal-Splay Sedimentation On Depositional Patterns and Stratigraphic Evolution In Avulsion-Dominated, Unconfined, Deep-Marine Basin-Floor Systems. J. Sediment. Res. 2016, 86, 786-799. [CrossRef]

97. Bayet-Goll, A.; de Carvalho, C.N. Architectural evolution of a mixed-influenced deltaic succession: Lower-to-Middle Ordovician Armorican Quartzite in the southwest Central Iberian Zone, Penha Garcia Formation (Portugal). Int. J. Earth Sci. 2020, 109, 2495-2526. [CrossRef] 